\title{
Risk Perception of Rural Land Supply Reform in China: From the Perspective of Stakeholders
}

\author{
Zhongqiong $Q u^{*}$, Yongxin Wei and Xun Li
}

Citation: Qu, Z.; Wei, Y.; Li, X. Risk Perception of Rural Land Supply

Reform in China: From the

Perspective of Stakeholders.

Agriculture 2021, 11, 646. https://

doi.org/10.3390/agriculture11070646

Academic Editors:

Francesco Caracciolo, Danilo Bertoni and Raffaele Cortignani

Received: 29 June 2021

Accepted: 7 July 2021

Published: 9 July 2021

Publisher's Note: MDPI stays neutral with regard to jurisdictional claims in published maps and institutional affiliations.

Copyright: (c) 2021 by the authors. Licensee MDPI, Basel, Switzerland. This article is an open access article distributed under the terms and conditions of the Creative Commons Attribution (CC BY) license (https:// creativecommons.org/licenses/by/ $4.0 /)$.
College of Public Administration, Nanjing Agricultural University, Nanjing 210095, China; 2018109049@njau.edu.cn (Y.W.); 1x@njau.edu.cn (X.L.)

* Correspondence: qzq@njau.edu.cn; Tel.: +86-199-6203-9178

\begin{abstract}
The reform of rural land supply market has a profound impact on the rural management and agricultural development. In this article, we want to explore risk perception of multi-subject land supply reform in China. The perception of potential risks from the perspective of stakeholders can evaluate the effect of a certain behavioral decision and provide a convincing explanation for further risk control. Based on theoretical analysis and practical investigation, we define the five stakeholders, namely collective economic organizations, farmers, local government, banks and land users, as the respondents of our questionnaire survey. Through in-depth interviews and literature review, we obtained the categories of risks with stakeholders. Data were obtained through questionnaire survey, a total of 307 surveys were conducted to analyze the probability of risk occurrence and the severity of consequences. Frequency analysis, risk matrix method, and Borda count method were used to analyze the survey results in order to determine the risk level and key risk. The research finds that the information asymmetry risk perceived by farmers and the market risk perceived by banks are key risks. In terms of stakeholders, famers and banks perceived the highest overall risks. It implies that the information-disadvantaged stakeholder is usually the one with a strong sense of risk.
\end{abstract}

Keywords: multi-subject land supply policy; risk perception; stakeholders; Wujin district in Jiangsu Province

\section{Introduction}

On 6 February 2020, the Chinese government released the annual policy guidelines on agriculture and rural development, also known as the 2020 No. 1 Document. In particular, the document stressed the country should encourage the development of various forms of moderate scale management, improve the agricultural socialized service system for small farmers and formulate the supporting system for rural collective operation construction land to enter the market [1]. China's land market has always been characterized by the dualtrack structure of urban and rural areas [2]. This system restricts the circulation of rural land, and it is impossible to transfer the ownership of rural land, namely rural collective economic organizations or individual farmers, directly urban users. Only through land expropriation of the government can rural land enter urban land market [3,4]. Such dualtrack land market system impairs the effectiveness of land transfer, which is not conducive to the improvement of agricultural production efficiency. On the other hand, it enlarges the gap of land profits between the urban and the rural area, which has a negative impact on farmers' well-being. In order to eliminate these disadvantages, China land administration department carried out a reform of land supply, which is called "multi-subject land supply". That is, multiple providers, such as rural collective economic organizations, original land user or others, can join in the land supply instead of the single pattern of government land supply. The new policy has aroused wide attention in academic circles. Some researchers have deliberated on the goals of multi-subject land supply, underlined necessity and significance of "multi-subject land supply" sufficiently [5-7], and predicted development trend of the reform from macro perspective [8]. However, evolution of the system is often 
accompanied with a series of contradictions and conflicts. Knowing risks is an important precondition for promoting the reform of the system, which aims to resolve contradictions and conflicts, and formulate risk control measures reasonably [9]. The kinds of risks that will affect providers, participants and stakeholders remain uncertain.

Risk cognition originates from the psychological concept of "risk is perception" [10,11]. Slovic [12] pointed out that, risk measurement mainly comes from subjective feelings and intuitive judgments, which is often referred to as risk perception. Risk perception reflects the values, ideology, and other sociocultural construction of the group [12,13]. It has been a common research paradigm to study how people address risk [10,14]. Risk perceptions of the public vary with policy domain, however, it is common for perceptions in all domains to vary with exogenous events or crises [15]. Many studies indicate that risk perception is an important mediator between risk communication and protective action [16-18]. It arises from a combination of cognitive assessments of risks and emotional perception of risks such as anxiety or worry, with the latter shaping perceptions of the former $[19,20]$. Numerous studies have shown that risk perception plays an important role in decision-making [21-24]. Risk perception understanding is the foundation of risk control [25]. Risk attitudes have been shown to be dependent on risk perception and have a strong domain-specific component $[26,27]$. Risk and uncertainty measurement is of paramount significance to both academics and practitioners particularly with respect to pricing, hedging and policymaking, etc. [24,28]. In addition, the agricultural sector is particularly fraught with uncertainty and risks, such as weather, pests and diseases, or changes in both market conditions and the policy context in which farmers operate and trade [29]. There is also a lot of literature on examining the impact of risk perception on agricultural policy [30-32]. European agricultural policies, such as the Common Agricultural Policy (CAP), emphasize the critical role of risk management tools $[33,34]$. Perceived barriers may influence farmers' intention to adopt the agricultural policy. As such, the higher the perceived barriers, the lower the intention to adopt the insurance and to participate in a mutual fund for farmers [35]. Land supply policy also has research on agricultural development and agricultural policy. Some scholars have shown that the supply of collective construction land squeezes the land space for rural industrial development and increases the conflicts with the agricultural land [36,37]. Fragmentary land structures and poor biophysical characteristics of land will increase farmland abandonment, and thus change the agricultural system [38].

In recent years, scholars have conducted more and more extensive theoretical and empirical research on risk perception, mainly concentrating on the study of risk perception mode [39], risk perception and control [40,41], the relationship between risk perception and cultural theory [42], risk perception and decision-making [43,44], link of risk attitudes, ambiguity attitudes, and time preferences, etc. [27]. Risk attitudes, risk perception are fundamental determinants behind risk management. However, risk is also unobservable and extremely difficult to measure. Hence, it is very important for policy-makers and researchers to adopt reliable methods to measure and understand farmers' risk attitudes [45]. Risk research methods also tend to be diversified, including risk perception research based on the intermediary model [46], evaluation of risk perception results by econometric model [47], risk perception analysis by the probabilistic method and stochastic programming model [48], and evaluation of public perception and attitude by risk matrix method [41], as well as using the Borda count method to rank the importance of risk [49]. These studies provide some good ideas, methods, and theoretical support for risk perception. The risk is closely relevant to the orientation of interest and decision-making of stakeholders [50-52]. Perception of potential risks from the perspective of stakeholders can provide a persuasive explanation for a certain decision [53]. The attitude and judgement come from stakeholders whose views on the policy can offer more direct and accurate understandings towards the possible risks [54-56].

The first innovation of this paper is, therefore, to combine the stakeholder theory with risk perception and from the stakeholder perspective to perceive the potential risk 
problems in the implementation of multi-subject land supply policy, especially to form the risk list based on different stakeholders. The second contribution of this paper is a comprehensive assessment of risk. We not only analyzed the probabilities and severity of the various risks, respectively, but also use risk matrix to comprehensively assess the level of risks. Furthermore, we also use the Borda count method to rank various risks. Through the analysis and application of various methods, these potential risks can be explored comprehensively and deeply. The article is divided into seven sections. In Section 1, we describe the background of multi-subject land supply and present a literature review. Section 2 introduces the policy of multi-subject land supply in China and its impact on rural development. The third defines the five stakeholders of multi-subject land supply. The fourth identifies types of potential risks. The fifth records research areas and methods, including the basis for selecting these methods. The sixth is the results analysis. The seventh is the conclusion and discussion.

\section{The Policy of Multi-Subject Land Supply in China and Its Impact on Rural Development}

The rural land supply reform referred to in this article is mainly multi-subject land supply. The concept of "multi-subject land supply" was formally proposed by China Government Work Report of 2017 [7], which stated "change the role of government as sole provider of residential land and establish a multi-subject housing supply system". The reform aims to optimize the structure of land supply and improve land use efficiency, release the function of land elements, and promote to establish the unified buildable land market in urban and rural areas. Land market includes various activities for land transactions and economic relations [57]. The same as the general commodity market, land market consists of four aspects, namely subjects, objects, managers, and trading places. Subjects of land market include land providers, land purchasers, and other participants. Land providers supply objects of transaction in land market, which are classified into two categories generally, the landowners and their representatives, or the land users that obtain the land use right from the governments or other land users, and then transfer it to other land users [57-59]. China is a country where urban land is owned by the public (namely public ownership of land) [60]. Urban land is owned by the State, with local governments acting as agents. Rural land is owned by village collective, with collective economic organizations acting as agents. Land ownership cannot be traded, but use right of the land can be provided in the land market by the government on behalf of the land owner [57].

Before the reform, the provider of state-owned land use right transfer market is national or local government in China, and rural construction land can enter land supply market only through land acquisition [61]. It means rural construction land could not be traded in land market without expropriation. With the process of the reform of multisubject land supply reform, the policy of collective land use has changed and the rural land market has been gradually opened. This change has revitalized the unused land resources in rural areas, and realizes the structural adjustment and layout optimization of land resources from the supply side [62]. Before multi-subject land supply were allowed, there were also some private land transactions unprotected or prohibited by law in the areas without proper enforcement of law [63]. Now, the transfer of collective construction land in the market has become legal and protected by the law. Such a reform is conducive to broadening the channels for collective land to enter the market and improve the use of idle rural land. Furthermore, the multi-channel land entering the market makes the value of collective land constantly manifest. The land profits obtained by farmers through collective construction land entering the market are greater than the compensation standard of land expropriation. The increase of farmers' collective income is conducive to rural revitalization and farmers' welfare [64]. 


\section{Definition of Stakeholders Involved in the Land Supply Reform}

In 1984, R. Edward Freeman originally elaborated the stakeholder theory of organizational management [65]. He proposed that a stakeholder is any person or entity that has a significant stake in the success or failure of a business, and they have a significant influence on the realization of an organization's goals [65]. Stakeholder theory offers a research framework for investigating the links between risk perception and the practice of stakeholder management $[66,67]$. There are many studies applying stakeholder theory to identify respondents, such as stakeholders in land use planning [68,69]. Or how to organize and identify stakeholders in agriculture region [70-72]. According to stakeholder theory, the stakeholders of multi-subject land supply can be defined as all individuals or entities that can influence the policy formulation, goal implementation or are affected by the policy implementation.

In China, rural construction land is collectively owned by the farmers in a collective. The construction land collectively owned by farmers is operated and managed by the local rural collective economic organization (RCEO) or village committee [60]. Therefore, collective economic organizations have a significant impact on and interests in dealing with the collectively owned land. They are provider of land, as well as the managers and agents. They deal with all the details of land transaction and determine the rules for the profit distribution from land sales [73]. They pursue the common interests of the village collective and also facilitate coordination between the farmers and land users, as well as raise funds for construction of collective lease houses. Farmers are individual owners of collective land and have the right to vote and to be informed when collective land is dealt with $[60,62]$. They can obtain a certain proportion profits from land profits. Farmers' interest appeal is that an individual's interests should not be infringed. Local governments undertake the important duties to formulate policy, improve local fiscal revenue and regulate land use planning $[59,74]$. They can exert certain intervention on land supply market and distribution of land value-added. The interest of the local government is to promote local economic development through the implementation of this policy without too much negative impact on the government. As important financial supporters of land transactions, banks and other financial institutions can provide debt financing plans to help land users to bridge the fund gap [75]. They always have sufficient funds to obtain use right of collective-owned construction land. The bank's interest is successful recovery of loans in order to gain interests and share. The interest appeal of land user lies in the minimum cost to gain the maximum benefit. Their market demand is an important drive to transact collective-owned construction land in market. As demanders of such land, land users have the usufruct to collective-owned construction land in the future [76]. Through the above analysis, we define the five types of stakeholders in this paper, namely collective economic organizations, farmers, local government, banks and land users.

\section{Identification of Risk Types of Different Stakeholders}

Risk perception is subjective judgment of people on uncertainty and severity of particular risk [53]. In the preliminary identification of risks, we conducted in-depth interviews with stakeholders to obtain the categories of risks. Then we listed the following types of risks in combination with relevant research literature.

For local government, with rapid development of economy, they are facing increasing financial pressure, which results in a large gap between income and expenditure. To meet financial demand from development, local governments began to manage land, and took advantage of land transfer fees to make up for the funds shortage [75]. Especially in recent years, local governments have raised larger and larger funds from operation of land, which overdraws the future land transfer earnings and causes strong correlation between local debt and with the land transfer [77] (as shown in A1 in Figure 1). Multi-subject land supply policy was proposed to promote the construction of urban and rural land markets and transact collective and state-owned buildable land with the same rights and prices [64]. The negative impact of this policy for the government is that it makes it more difficult to 
expropriate land in the future, such as less scope of expropriation, high compensation for expropriation instead of previous "expropriation at low cost, sales at high price" (as shown in A2 in Figure 1), which will further affect land revenue of local government, aggravate the risk of debt crisis and even lead to financial crisis [73]. In the case of single-subject land supply, the government had complete control over the amount of land supply each year. The advantage is that annual land supply is stable without oversupply of land in real estate market, but the circumstances change now. The high profits from collective land transfer drive collective organizations to sell land instead of being expropriated. The collective economic organizations may oversupply land [78] (as shown in A4 in Figure 1). On the other hand, since more profits can be obtained from transaction of the collectiveowned land, the collective economic organizations may change some agricultural land or some land not for construction purpose in market. They may also change non-operating buildable land into collective-owned construction land for transaction [73] (as shown in A3 in Figure 1). The negative effect of such practice is manifold, such as changing usage of land, violating law or regulation on land use, incompliance with expectations of land use planning. Furthermore, the housing policy of "both rent and purchase" makes it possible to sell or lease collective land [5]. These changes may also have an influence on the real estate market (as shown in A5 in Figure 1). Based on the above, we summarize the potential risks perceived by the government as shown in Figure 1.

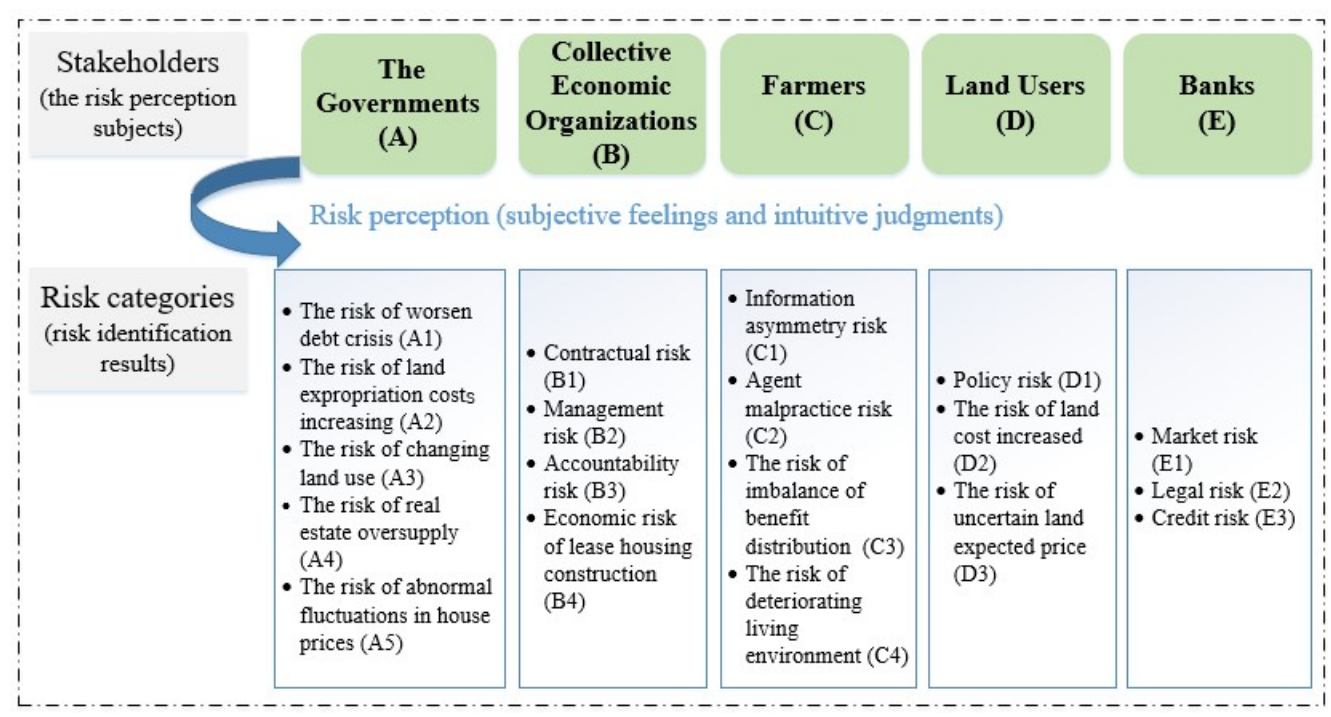

Figure 1. Categorizing risks from the perspective of stakeholders. The letter A in Figure 1 represents the potential risks perceived by the government. The $\mathrm{B}$ represents the risks perceived by collective economic organizations. The $\mathrm{C}$ represents the risks perceived by farmers, $\mathrm{D}$ represents the risks perceived by land users, and $\mathrm{E}$ represents the risks perceived by banks or financial institutions.

For collective economic organizations, they are not only executor and promoter of marketization of collective construction land, but also the "agent" of transaction in collective land [61]. They should not only sign the land transaction agreements with land users, but also supervise the land user regarding how to develop land after the transaction. Moreover, they should explain relevant policies to farmers and solve contradictions and disputes. Therefore, contractual risk (B1) and management risk (B2), etc., are main risks exposed to collective economic organizations. In addition, if land users fail to use the land following the purpose agreed in the contact, the collective economic organization will be punished as the responsible person [79] (B3). Furthermore, according to the new housing system, rental houses can be constructed on collective land, which means collective economic organizations become one of the providers of lease housing [59]. However, the construction requires huge funds and the investment payback period is long, most collective economic organizations do not have sufficient start-up funds (B4). The economic 
feasibility in construction of lease housing has been a key concern of collective economic organizations. Thus, we summarize potential risks perceived by the collective economic organizations as shown in Figure 1.

Our survey indicated that farmers' participation in collective land transactions is inadequate. During the marketization of collective-owned construction land, each participant has its own interest claims. The distribution of land appreciation is essentially a game among all stakeholders, and the result depends on the game ability of each stakeholder [80]. In this game, the individual farmer is the weakest player. They know little about the policy and trade information related to such transaction, so they are exposed to greater risk from information asymmetry (C1). Moreover, the income distribution mechanism is immature yet [6] (C3). Collective economic organizations, as agents, play a leading role in transactions of collective land transactions and distribution of profit. They have major economic and political rights, which can create greater malpractice space for them [79]. They are likely to manipulate their privileges for illegal earnings from sales of collective land. Once this has happened, it will harm interests of farmers (C2). The reform can arouse people's enthusiasm for development of collective land, but land development or village reconstruction are likely to cause long-term pollution of air and noise, which brings the risk to farmers in deterioration of living environment [22] (C4). Therefore, we summarize potential risks perceived by farmers as shown in Figure 1.

For land users, the cost of collective-owned construction land use right is relatively low, while the profits from future land development will be high. This is a huge profit temptation for land users. However, the reform has only started a few years ago, the legal systems and trade procedures need to be improved further. The policy and financial guarantee mechanism after acquiring the land use right are not sound yet [64,74]. Therefore, land users are still exposed to some potential risks, such as change in policy (D1), uncertainty in future land prices (D3). Moreover, collective economic organizations are likely not able to provide "Net Land". "Net Land" refers to the land with clear ownership to the land and its attachments, without conflict in compensation for land acquisition, free of legal and economic disputes, with planning conditions and basic conditions necessary for development [57]. If the land provided by collective economic organization does not meet the condition of "Net Land", the land users should pay the extra costs (D2). Thus, we summarize the potential risks perceived by land users as shown in Figure 1.

In the practice of multi-subject land supply, banks and other financial institutions, as financial supporters, are likely to face problems, such as bad debts and losses, due to future change of market, decrease in local land fiscal revenue, and operating losses of land users (E1). Currently, legal definitions on collective land owners are still relatively fuzzy [60], and there are some disputes over the ownership of land use right and issuance of land registration certificate [81]. If there is any doubt about ownership of mortgaged land, banks and other financial institutions may face certain legal risks (E2). In addition, when banks grant loans, they usually assess the credit and comprehensive solvency of the borrower according to his morality, ability, capital, collateral, operating environment, and other factors, and then decide whether to grant the loan or not [82]. If the borrower fails to repay the principal and interest of the loan according to the contract, the bank may suffer from losses and face huge credit risk (E3). Hence, we summarize the potential risks perceived by banks as shown in Figure 1 .

\section{Study Area and Methods}

\subsection{Study Area}

Wujin District in Jiangsu Province was selected as the research area for two reasons. Firstly, it is the first pilot area in marketization reform of collective-owned construction land in Jiangsu Province. Secondly, it is the birthplace of the "Southern Jiangsu Model" with developed land market [83]. By September 2019, a total of 10,032 cases of collectiveowned construction land had been traded in primary land market, and the signing rate of paid use contracts reached $98 \%$. Among them, 1145 cases were transferred by agreement, 
109 cases were transferred by bidding, auction, and listing, 8768 cases were leased by agreement, 3 cases were leased by bidding, auction, and listing, and 7 cases of land were converted into shares at fixed price. In the secondary land market, there are 618 collectiveowned construction land transactions totally, including 108 transfer transactions and 510 mortgage transactions (data sources: according to the Jiangsu land market network (http:/ / www.landjs.com/jtjsyd/ (accessed on 20 October 2019)) provides data sorting). Wujin District has made remarkable achievements since the pilot reform. It has established a trading platform for collective-owned land and promotes the construction of unified buildable land market in urban and rural areas. Its practice and experience can bring certain demonstration and leading effects to other regions. Its primary land supply market transactions mainly include governmental allocation, transfer and trade of collective-owned construction land. In the secondary market, transfer and mortgage of land are the main forms of transaction [57].

\subsection{Research Approach and Questionnaire Design}

According to the definition of risk in Knight's book, Risk Uncertainty and Profit, risk is a group of probabilistic events [84]. In the process of research, risk can be converted into the probability of some uncertain events for quantitative analysis. The risk matrix method is a commonly used analysis method, which is very suitable for risk identification, risk analysis and risk evaluation $[49,85]$. The risk matrix assesses a risk level by the probability of the risk occurring and severity of consequences [86,87]. The main advantage of the risk matrix is that complex risk data are simplified in a compressed form. However, there are several significant disadvantages, as well. Firstly, it is a user perspective approach; the same matrix can be interpreted differently by another user unless each condition is clearly described. Secondly, it is often found oversimplified which cannot capture the detailed process risk profile [87]. To overcome such limitation, we made two improvements. Firstly, we designed respective questionnaires for different stakeholders, and the number of questionnaires distributed is also different. Secondly, we used Borda count method to rank the risks in order to make up for the deficiency of risk matrix. The Borda count method is used in voting and decision-making. The method requires voters not only to express their preference for a candidate, but also to rank the qualified candidates, and then to score and sum them up. The one with the highest score wins [88-90].

In the questionnaire design of this paper, we set up the questions according to the probability and severity of the risk matrix, as shown in Appendix A. We used Likert scale method to measure the risk probability: "Almost certain to happen" is a score of 5, "frequent" is a score of 4, "several times" is a score of 3, "possible but never happened" is a score of 2, and "rare" is a score of 1 . There are also five levels of severity, with "most severe" at 5 , "relatively severe" at 4 , "moderate" at 3, "slight" at 2, and "almost no damage" at 1. The scores on the vertical and horizontal axis were added to assess the level of risk. The risk with score of less than 2 is considered as very low risk, expressed in white; risk with score of 3-4 is classified as low risk, shown in light gray; risk with score of 5-6 is classified as moderate risk (or medium risk), indicated in gray; risk with score of 7-8 is considered high risk, expressed in dark gray; a risk with score above 9 is considered very high risk, shown in black. The risk matrix of this paper is shown in Table 1 . The evaluation criteria of the questionnaire are as mentioned above, that is, 1 point for very low risk probability or severity, and 5 points for very high. 
Table 1. Risk matrix.

\begin{tabular}{|c|c|c|c|c|c|c|}
\hline \multirow{2}{*}{\multicolumn{2}{|c|}{$\begin{array}{c}\text { 0-2 = Very Low Risk } \\
\text { 3-4 = Low Risk } \\
\text { 5-6 = Moderate Risk } \\
\text { 7-8 = High Risk } \\
\text { 9-10 = Very High Risk }\end{array}$}} & \multicolumn{5}{|c|}{ Loss Rate } \\
\hline & & $\begin{array}{c}\text { Most } \\
\text { Severe: } 5\end{array}$ & $\begin{array}{c}\text { Relatively } \\
\text { Severe: } 4\end{array}$ & $\begin{array}{c}\text { Moderate: } \\
3\end{array}$ & Slight: 2 & $\begin{array}{l}\text { Almost No } \\
\text { Damage: } 1\end{array}$ \\
\hline \multirow{5}{*}{ 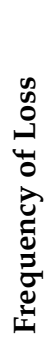 } & $\begin{array}{l}\text { Almost Certain to } \\
\text { Happen: } 5\end{array}$ & 10 & 9 & 8 & 7 & 6 \\
\hline & Frequent: 4 & 9 & 8 & 7 & 6 & 5 \\
\hline & Several Times: 3 & 8 & 7 & 6 & 5 & 4 \\
\hline & $\begin{array}{c}\text { Possible but Never } \\
\text { Happened: } 2\end{array}$ & 7 & 6 & 5 & 4 & 3 \\
\hline & Rare: 1 & 6 & 5 & 4 & 3 & 2 \\
\hline
\end{tabular}

\section{Results}

\subsection{Sample Characteristics Analysis}

According to the questionnaire in Appendix A, we conducted interviews with different stakeholders to obtain research data. The respondents are the five stakeholders described in Section 3. They were asked to score the severity and probability of risk type based on questions in Appendix A. We chose some respondents for in-depth interviews, aiming to obtain more information to qualitatively analyze the actual impact of policy implementation and enrich the survey results. Among all the stakeholders, collective economic organizations, which play the dual role of agent and manager, are undoubtedly the most important. Therefore, we conducted in-depth interviews with all respondents of collective economic organizations and 15 20\% of respondents from other stakeholders in order to acquire more recessive detail. These details help us to better dissect the reasons and realities behind the data. The survey was conducted between June and September 2019, selecting seven towns in Wujin District. In total, 307 questionnaires are confirmed to be valid, with a recovery rate of $87.7 \%$. Among them, there are total 26 questionnaires for the government staff, 71 for collective economic organizations, 152 for farmers, 33 for land users, and 25 for bank staff. More characteristics of respondents can be obtained from Table 2. It can be seen that gender, age, education and income all have their own representation.

Table 2. Sample characteristics of the questionnaire administered.

\begin{tabular}{|c|c|c|c|c|c|c|c|}
\hline \multirow{2}{*}{\multicolumn{2}{|c|}{$\begin{array}{l}\text { Characteristics of } \\
\text { Respondents }\end{array}$}} & \multicolumn{5}{|c|}{ Stakeholders } & \multirow[b]{2}{*}{ Total } \\
\hline & & $\begin{array}{c}\text { The } \\
\text { Government } \\
\text { Staffs }\end{array}$ & $\begin{array}{c}\text { Collective } \\
\text { Economic } \\
\text { Organizations }\end{array}$ & Farmers & Land Users & Bank Staffs & \\
\hline & & $\begin{array}{l}\text { Number and } \\
\text { Percentage }\end{array}$ & $\begin{array}{l}\text { Number and } \\
\text { Percentage }\end{array}$ & $\begin{array}{l}\text { Number and } \\
\text { Percentage }\end{array}$ & $\begin{array}{l}\text { Number and } \\
\text { Percentage }\end{array}$ & $\begin{array}{l}\text { Number and } \\
\text { Percentage }\end{array}$ & $\begin{array}{c}\text { Number and } \\
\text { Percentage }\end{array}$ \\
\hline \multirow{2}{*}{ Gender } & Male & $\begin{array}{c}16 \\
5.2 \%\end{array}$ & $\begin{array}{c}47 \\
15.3 \%\end{array}$ & $\begin{array}{c}92 \\
30.0 \%\end{array}$ & $\begin{array}{c}29 \\
9.4 \%\end{array}$ & $\begin{array}{c}19 \\
6.2 \%\end{array}$ & $\begin{array}{l}203 \\
66 \%\end{array}$ \\
\hline & Female & $\begin{array}{c}10 \\
3.3 \%\end{array}$ & $\begin{array}{c}24 \\
7.8 \%\end{array}$ & $\begin{array}{c}60 \\
19.5 \%\end{array}$ & $\begin{array}{c}4 \\
1.3 \% \\
\end{array}$ & $\begin{array}{c}6 \\
2.0 \% \\
\end{array}$ & $\begin{array}{l}104 \\
34 \% \\
\end{array}$ \\
\hline \multirow[b]{3}{*}{ Age } & Under 25 years old & $\begin{array}{c}2 \\
0.7 \%\end{array}$ & $\begin{array}{c}6 \\
2.0 \%\end{array}$ & $\begin{array}{c}12 \\
3.9 \%\end{array}$ & $\begin{array}{c}0 \\
0.0 \%\end{array}$ & $\begin{array}{c}0 \\
0.0 \%\end{array}$ & $\begin{array}{c}20 \\
7 \%\end{array}$ \\
\hline & 26-35 years old & $\begin{array}{c}4 \\
1.3 \%\end{array}$ & $\begin{array}{c}25 \\
8.1 \%\end{array}$ & $\begin{array}{c}28 \\
9.1 \%\end{array}$ & $\begin{array}{c}8 \\
2.6 \%\end{array}$ & $\begin{array}{c}9 \\
2.9 \%\end{array}$ & $\begin{array}{c}74 \\
24 \%\end{array}$ \\
\hline & $36-45$ years old & $\begin{array}{c}8 \\
2.6 \%\end{array}$ & $\begin{array}{c}20 \\
6.5 \%\end{array}$ & $\begin{array}{c}37 \\
12.1 \%\end{array}$ & $\begin{array}{c}11 \\
3.6 \%\end{array}$ & $\begin{array}{c}10 \\
3.3 \%\end{array}$ & $\begin{array}{c}86 \\
28 \%\end{array}$ \\
\hline
\end{tabular}


Table 2. Cont.

\begin{tabular}{|c|c|c|c|c|c|c|c|}
\hline \multirow{3}{*}{\multicolumn{2}{|c|}{$\begin{array}{l}\text { Characteristics of } \\
\text { Respondents }\end{array}$}} & \multicolumn{5}{|c|}{ Stakeholders } & \multirow[b]{2}{*}{ Total } \\
\hline & & \multirow{2}{*}{$\begin{array}{c}\text { The } \\
\text { Government } \\
\text { Staffs } \\
\begin{array}{c}\text { Number and } \\
\text { Percentage }\end{array}\end{array}$} & \multirow{2}{*}{$\begin{array}{c}\text { Collective } \\
\text { Economic } \\
\text { Organizations } \\
\begin{array}{c}\text { Number and } \\
\text { Percentage }\end{array} \\
\end{array}$} & \multirow{2}{*}{$\begin{array}{c}\text { Farmers } \\
\begin{array}{c}\text { Number and } \\
\text { Percentage }\end{array}\end{array}$} & \multirow{2}{*}{$\begin{array}{l}\text { Land Users } \\
\begin{array}{c}\text { Number and } \\
\text { Percentage }\end{array}\end{array}$} & \multirow{2}{*}{$\begin{array}{c}\text { Bank Staffs } \\
\begin{array}{c}\text { Number and } \\
\text { Percentage }\end{array}\end{array}$} & \\
\hline & & & & & & & $\begin{array}{c}\text { Number and } \\
\text { Percentage }\end{array}$ \\
\hline & $46-55$ years old & $\begin{array}{c}8 \\
2.6 \%\end{array}$ & $\begin{array}{c}15 \\
4.9 \%\end{array}$ & $\begin{array}{c}49 \\
16.0 \%\end{array}$ & $\begin{array}{c}9 \\
2.9 \%\end{array}$ & $\begin{array}{c}6 \\
2.0 \%\end{array}$ & $\begin{array}{c}87 \\
28 \%\end{array}$ \\
\hline & Over 56 years old & $\begin{array}{c}4 \\
1.3 \%\end{array}$ & $\begin{array}{c}5 \\
1.6 \%\end{array}$ & $\begin{array}{c}26 \\
8.5 \%\end{array}$ & $\begin{array}{c}5 \\
1.6 \%\end{array}$ & $\begin{array}{c}0 \\
0.0 \%\end{array}$ & $\begin{array}{c}40 \\
13 \%\end{array}$ \\
\hline \multirow{5}{*}{$\begin{array}{l}\text { Education } \\
\text { level }\end{array}$} & $\begin{array}{c}\text { Junior high school } \\
\text { and below }\end{array}$ & $\begin{array}{c}0 \\
0.0 \%\end{array}$ & $\begin{array}{c}3 \\
1.0 \%\end{array}$ & $\begin{array}{c}63 \\
20.5 \%\end{array}$ & $\begin{array}{c}0 \\
0.0 \%\end{array}$ & $\begin{array}{c}0 \\
0.0 \%\end{array}$ & $\begin{array}{c}66 \\
21 \%\end{array}$ \\
\hline & High school & $\begin{array}{c}0 \\
0.0 \%\end{array}$ & $\begin{array}{c}18 \\
5.9 \%\end{array}$ & $\begin{array}{c}35 \\
11.4 \%\end{array}$ & $\begin{array}{c}7 \\
2.3 \%\end{array}$ & $\begin{array}{c}0 \\
0.0 \%\end{array}$ & $\begin{array}{c}60 \\
20 \%\end{array}$ \\
\hline & Junior college & $\begin{array}{c}0 \\
0.0 \%\end{array}$ & $\begin{array}{c}19 \\
6.2 \%\end{array}$ & $\begin{array}{c}30 \\
9.8 \%\end{array}$ & $\begin{array}{c}12 \\
3.9 \%\end{array}$ & $\begin{array}{c}3 \\
1.0 \%\end{array}$ & $\begin{array}{c}64 \\
21 \%\end{array}$ \\
\hline & Undergraduate & $\begin{array}{c}14 \\
4.6 \% \\
\end{array}$ & $\begin{array}{c}26 \\
8.5 \% \\
\end{array}$ & $\begin{array}{c}24 \\
7.8 \% \\
\end{array}$ & $\begin{array}{c}14 \\
4.6 \% \\
\end{array}$ & $\begin{array}{c}15 \\
4.9 \% \\
\end{array}$ & $\begin{array}{c}93 \\
30 \% \\
\end{array}$ \\
\hline & $\begin{array}{c}\text { Master's degree } \\
\text { and above }\end{array}$ & $\begin{array}{c}12 \\
3.9 \%\end{array}$ & $\begin{array}{c}5 \\
1.6 \%\end{array}$ & $\begin{array}{c}0 \\
0.0 \%\end{array}$ & $\begin{array}{c}0 \\
0.0 \%\end{array}$ & $\begin{array}{c}7 \\
2.3 \%\end{array}$ & $\begin{array}{c}24 \\
8 \%\end{array}$ \\
\hline \multirow{4}{*}{$\begin{array}{l}\text { Monthly } \\
\text { income }\end{array}$} & Below CNY 2000 & $\begin{array}{c}0 \\
0.0 \%\end{array}$ & $\begin{array}{c}4 \\
1.3 \%\end{array}$ & $\begin{array}{c}59 \\
19.2 \%\end{array}$ & $\begin{array}{c}0 \\
0.0 \%\end{array}$ & $\begin{array}{c}0 \\
0.0 \%\end{array}$ & $\begin{array}{c}63 \\
21 \%\end{array}$ \\
\hline & CNY 2000-5000 & $\begin{array}{c}2 \\
0.7 \% \\
\end{array}$ & $\begin{array}{c}60 \\
19.5 \% \\
\end{array}$ & $\begin{array}{c}74 \\
24.1 \% \\
\end{array}$ & $\begin{array}{c}0 \\
0.0 \% \\
\end{array}$ & $\begin{array}{c}19 \\
6.2 \% \\
\end{array}$ & $\begin{array}{l}155 \\
50 \% \\
\end{array}$ \\
\hline & CNY 5000-10,000 & $\begin{array}{c}20 \\
6.5 \%\end{array}$ & $\begin{array}{c}7 \\
2.3 \%\end{array}$ & $\begin{array}{c}19 \\
6.2 \%\end{array}$ & $\begin{array}{c}9 \\
2.9 \%\end{array}$ & $\begin{array}{c}6 \\
2.0 \%\end{array}$ & $\begin{array}{c}61 \\
20 \%\end{array}$ \\
\hline & Over CNY 10,000 & $\begin{array}{c}4 \\
1.3 \%\end{array}$ & $\begin{array}{c}0 \\
0.0 \%\end{array}$ & $\begin{array}{c}0 \\
0.0 \%\end{array}$ & $\begin{array}{c}24 \\
7.8 \%\end{array}$ & $\begin{array}{c}0 \\
0.0 \%\end{array}$ & $\begin{array}{c}28 \\
9 \%\end{array}$ \\
\hline \multicolumn{2}{|c|}{ Total } & $\begin{array}{c}26 \\
8.5 \%\end{array}$ & $\begin{array}{c}71 \\
23.1 \%\end{array}$ & $\begin{array}{c}152 \\
49.5 \%\end{array}$ & $\begin{array}{c}33 \\
10.7 \%\end{array}$ & $\begin{array}{c}25 \\
8.1 \%\end{array}$ & $\begin{array}{c}307 \\
100 \%\end{array}$ \\
\hline
\end{tabular}

\subsection{Questionnaire Reliability Test}

Reliability analysis is used to analyze the reliability and accuracy of answers to quantitative data. Generally speaking, it is considered academically that if the value of Cronbach alpha coefficient is higher than 0.8 , this means high reliability. If this value is between 0.7 and 0.8 , it means that the reliability is good. If this value is between 0.6 and 0.7 , the reliability is acceptable. If the value is less than 0.6 , the reliability is poor, and it is necessary to increase and delete the set item to verify the stability of the model through internal consistency [91,92]. The results of questionnaire reliability are shown in Table 3.

As can be found from the table above, the value of Cronbach alpha coefficient of the total sample is 0.828 , which is higher than 0.8 , which indicates that the comprehensive reliability of the data is high and the obtained data can be used for further analysis. In addition, it can be seen that the value of Cronbach alpha coefficients of each research factor are all higher than 0.6 , indicating that the reliability of the research data is acceptable or even better.

\subsection{Frequency Analysis of Risk Probability and Severity}

In order to eliminate possible influences of different numbers of questionnaires distributed among stakeholders, we chose frequency analysis method. Frequency is the number of times an event occurs. Frequency analysis obtains the occurrence frequency of each value by grouping the same value data into a group and measures of central tendency, dispersion, percentile $[93,94]$. Figure 2 shows the frequency of risk probability and Figure 3 shows the risk severity. The five colors represent different risk grades, and the length of each color in the bar chart represents the frequency of the grade. For example, 
in Figure 2, the green length of E3 is the longest and the green represents low probability of risk occurrence, thus indicating that E3 has the highest frequency of low risk.

Table 3. Questionnaire reliability test results.

\begin{tabular}{cc}
\hline Research Factor & Cronbach Alpha Coefficient \\
\hline A1 & 0.801 \\
A2 & 0.787 \\
A3 & 0.655 \\
A4 & 0.815 \\
A5 & 0.923 \\
B1 & 0.697 \\
B2 & 0.681 \\
B3 & 0.647 \\
B4 & 0.868 \\
C1 & 0.834 \\
C2 & 0.755 \\
C3 & 0.880 \\
C4 & 0.857 \\
D1 & 0.930 \\
D2 & 0.859 \\
D3 & 0.871 \\
E1 & 0.954 \\
E2 & 1.000 \\
E3 & 0.625 \\
Total sample & 0.828 \\
\hline
\end{tabular}

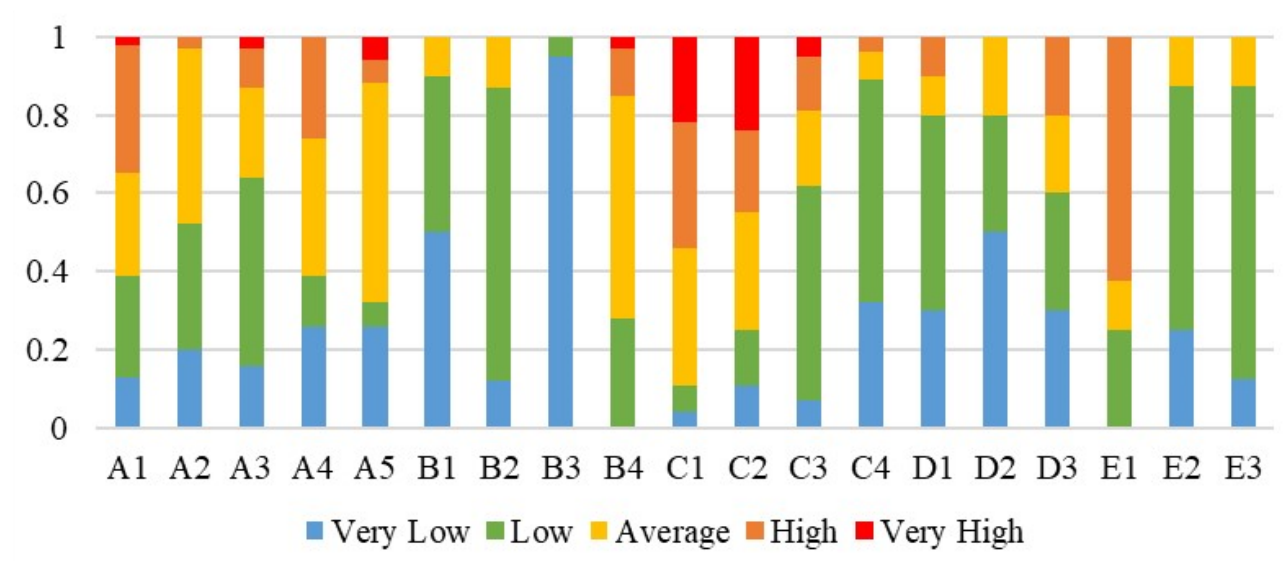

Figure 2. The frequency analysis of risk probability of multi-subject land supply from the perspective of the stakeholders.

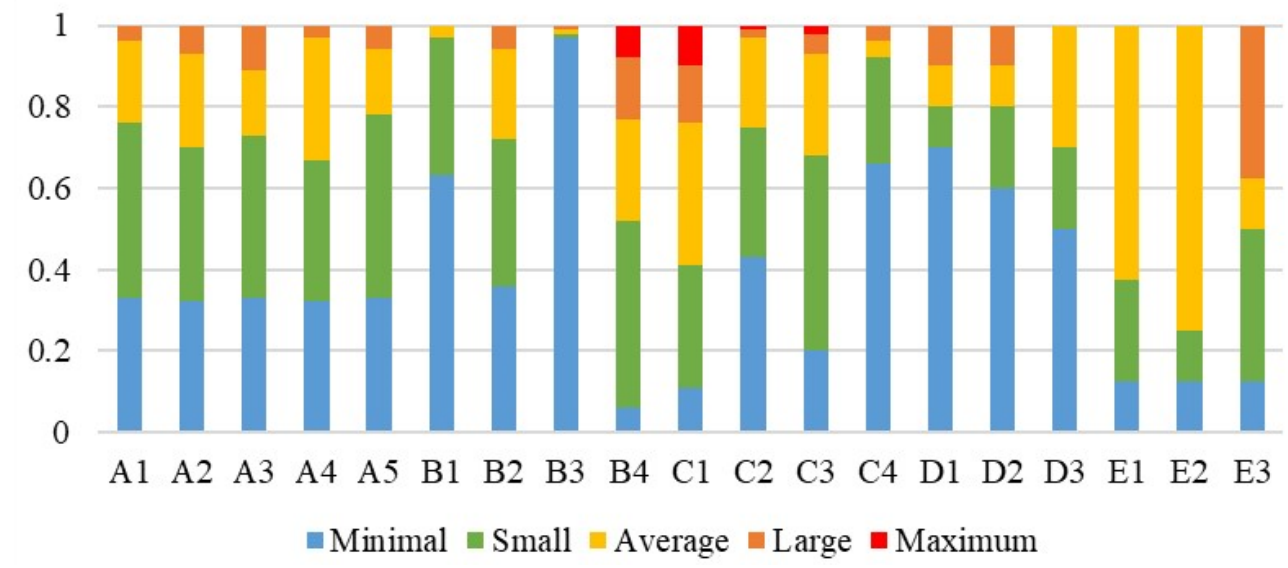

Figure 3. The frequency analysis of risk severity of multi-subject land supply from the perspective of the stakeholders. 
In terms of risk probability, the results show that each risk probability perceived by governments is not high generally. The probability of increased land expropriation cost (A2) is at average level or lower, which indicates that the multi-subject land supply may not have a great impact on the land expropriation. According to our survey, local government conducts a social risk evaluation and formulates detailed compensation standards for land expropriation. The governmental officers believe that these countermeasures could control the cost of land expropriation. However, there are some risks that should be noticed. Approximately $60 \%$ or more respondents perceive the risk of worsening debt crisis (A1), the risk of real estate oversupply (A4) and the risk of abnormal fluctuations in house prices (A5) are likely to occur. As for the risk from changing land use (A3), most governmental officers believe that the probability of occurrence is relatively "low", while others think it is "very high". Although there are individual differences in risk perception, it also indicates that the risk is uncertain. In terms of risk severity, there is little difference in the effect degree of various risks, which is at average level or below. This indicates that, if the risk occurs, the governmental officers believe they can play the role of macro control and take countermeasures to reduce the effect.

Overall risk probability perceived by collective economic organizations is not high. The reasons may be that they are the agent of transaction of collective-owned construction land. They are very passionate about this policy and may ignore some risks, therefore, they perceive that all risks are at average level or below. The risk in inadequate funds for construction of lease houses on collective buildable land (B4) is distressing. The results show that more than $70 \%$ of respondents perceive the economic risk of lease housing construction (B4) is at average level or above. Among them, a small number of collective economic organizations perceive the risk probability to be "high" or even "very high". The results indicate that the severity of this risk is relatively "large" once it occurs, mainly because of huge investment in construction of public lease houses, long recovery period, and lack of capital and development and operation abilities of collective economic organizations.

From the perspective of farmers, respondents perceive that the risk probability is relatively high, and overall level is at above average level, especially the information asymmetry risk (C1) and agent malpractice risk (C2). About half of the respondents perceive the possibility of information asymmetry risk (C1) and agent malpractice risk (C2) to be "high" or above. Besides, the risk from imbalance of benefit distribution (C3) is also relatively high, about $40 \%$ of respondents perceive the probability of such risk is at average level or above. Furthermore, the risk severity perceived by farmers is at average level overall. Only the information asymmetry risk (C1) is relatively high. It can be seen from the survey information that collective economic organizations control the land transaction and benefit distribution, while farmers have little knowledge of policies and slight participation in transaction of collective land. Therefore, farmers perceive the severity of risk is relatively high.

For land users, the risk probability and severity perceived are at average level or below. In total, $80 \%$ of respondents perceive a "low" or "very low" probability and severity of policy risk (D1) and the risk in increase of land cost (D2). The risk most likely to occur is the risk of uncertain land expected price (D3). The reason may be that the reform is still in the pilot stage, and multiple-subject land supply has not been implemented nationwide. Some policies to protect the interests of land users are not perfect enough, which may affect the evaluation of expected returns in the future and increase the uncertainty of such risk. From the perspective of banks and other financial institutions, the results show that the probability of market risk (E1) is relatively high, and more than $60 \%$ of respondents perceive that probability of market risk is at a "high" level, while the respondents believe that the severity is at average level if the risk occurs. The credit risk (E3) is less likely to occur, while the severity is relatively high. The reason may be that bank or other financial institutions provide land users with high land transfer loans. If the loans cannot be repaid on time, banks will face huge income losses. 


\subsection{Determination of Risk Level Based on Risk Matrix Method}

Frequency analysis is only a statistical analysis of the distribution of options and does not involve the evaluation of the level of risk. Therefore, next, we use the risk matrix method to determine the risk level $[49,85]$, the score of risk level is obtained from calculating the scores of risk probability and severity comprehensively. The probability score and severity score of each risk are obtained from calculating average of the results of questionnaires. The judgment of risk level is classified according to the risk matrix method (as shown in Table 1). The results are shown in Figure 4. The information asymmetry risk (C1) and the market risk (E1) are at high level, while remaining risks are at average level or below. The level of accountability risk (B3) is the lowest, with small probability and severity. We learn that the supervision and management after land transaction are relatively good and land users scarcely change the land use or violate land use contract in the investigation area. According to the comprehensive analysis of risks, it can be found that risk level perceived by local government is moderate, risk level perceived by collective economic organizations and land users is relatively low, and risk level perceived by farmers and banks are at high level. It implies that ill-informed stakeholders are usually the ones with strong perception of risk.

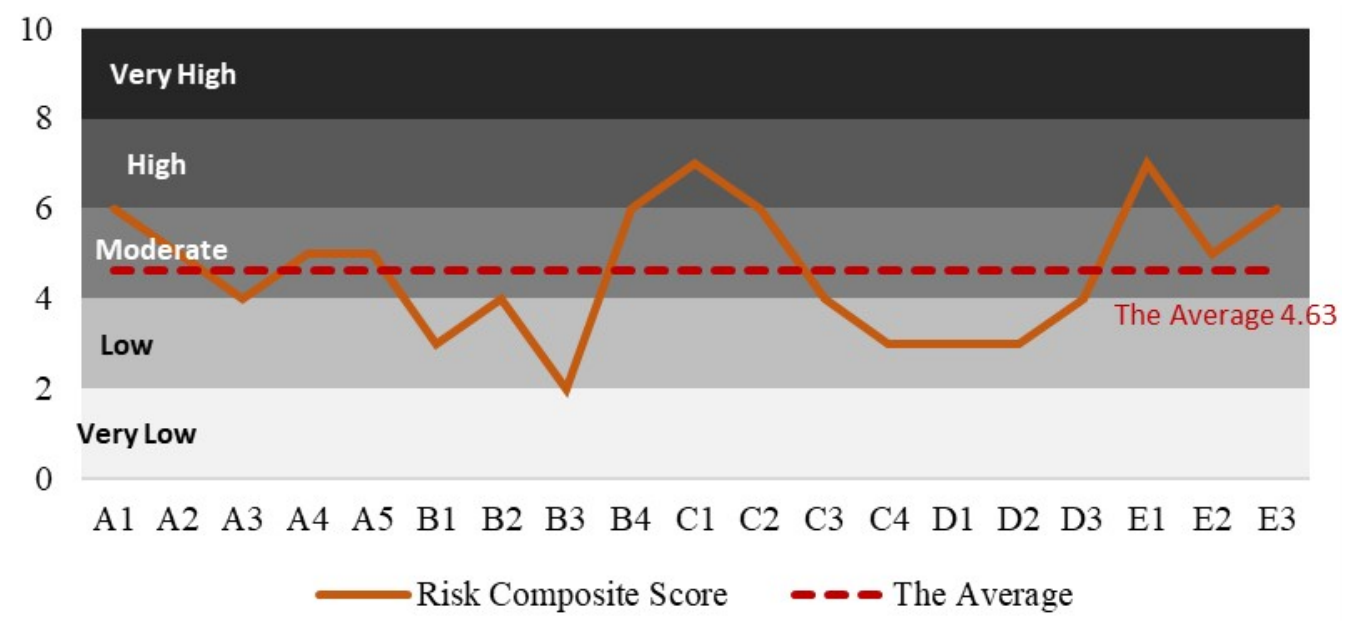

Figure 4. Based on the risk probability of Figure 2 and the risk severity of Figure 3, Figure 4 shows the result of the various risk level calculated using risk matrix method.

\subsection{Risk Type Ranking Based on Borda Count Method}

\subsubsection{Determination of Ordinal Value for Risk Probability}

The purpose of the Borda Count Method is to be able to select different options and rank the risk type. The ordinal value of risk probability is determined by the ranking result according to its probability of occurrence [49]. According to the questionnaire, the probability of risk factors is classified into five grades: very high, high, average, low and very low, so we use " $h$ " to represent the number of probability levels, and $h$ is from 1 to 5 . " $G_{h}$ " represents the probability level, then $G_{1}=$ very high, $G_{2}=$ high, $G_{3}=$ average, $G_{4}=$ low, $G_{5}=$ very low. " $N_{h}$ " represents the number of risk factors with " $G_{h}$ " risk probability level. " $P_{h}$ " represents the ordinal value of risk probability corresponding to the probability level of " $G_{h}$ ", calculated as following:

$$
\begin{gathered}
P_{h}=B_{h}+\left(1+N_{h}\right) / 2 \\
B_{h}=\sum_{r=1}^{h-1} N_{r}\left(h>1, h=1, B_{h}=0\right)
\end{gathered}
$$

According to the risk probability results (as shown in Figure 5), we can obtain the number of each probability level: $N_{1}=0, N_{2}=4, N_{3}=5, N_{4}=9, N_{5}=1$. According to 
Formulas (1) and (2), the ordinal value of risk probability " $P_{h}$ " of each probability level is calculated as following (as shown in Figure 6):

$$
\begin{gathered}
P_{1}=B_{1}+\frac{\left(1+N_{1}\right)}{2}=\frac{1}{2} ; P_{2}=B_{2}+\frac{\left(1+N_{2}\right)}{2}=\frac{5}{2} ; P_{3}=B_{3}+\frac{\left(1+N_{3}\right)}{2}=7 ; \\
P_{4}=B_{4}+\frac{\left(1+N_{4}\right)}{2}=14 ; P_{5}=B_{5}+\frac{\left(1+N_{5}\right)}{2}=19
\end{gathered}
$$

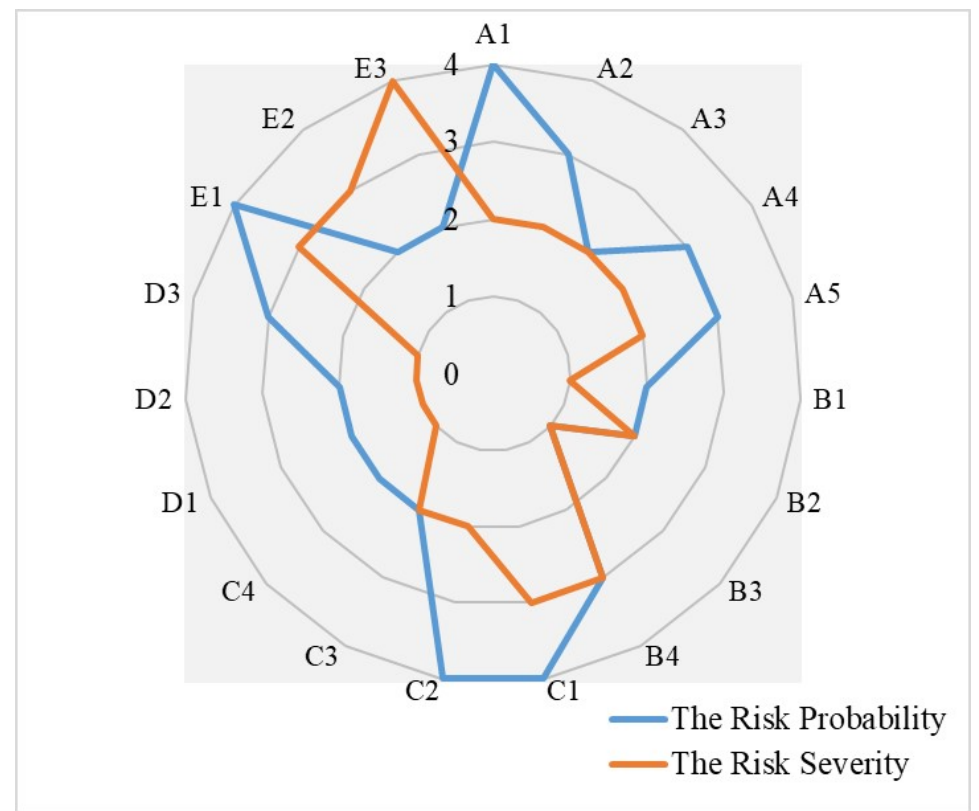

Figure 5. The risk probability and severity results.

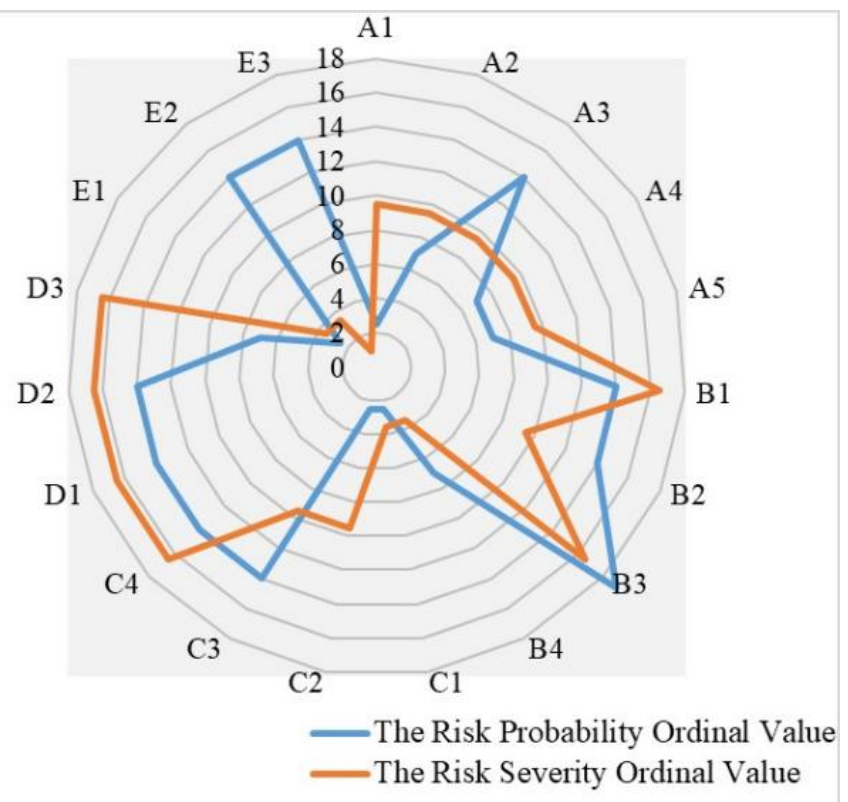

Figure 6. Ordinal value for risk probability and severity.

\subsubsection{Determination of Ordinal Value for Risk Severity}

The ordinal value of risk severity is determined by the ranking result according to the effect of risk factors on risk bearers [49]. According to the questionnaire, the severity results include "maximum", "large", "average", "small" and "minimal". We use " $j$ " to represent the number of risk severity levels, and $j$ is from 1 to 5 . We use " $Q_{j}$ " to represent the risk 
severity level, then $Q_{1}=$ maximum, $Q_{2}=$ large, $Q_{3}=$ average, $Q_{4}=$ small, $Q_{5}=$ minimal. " $M_{j}$ " represents the number of risk factors with risk severity level of " $Q_{j}$ ". " $I_{j}$ " represents the ordinal value of risk severity corresponding to the severity level of " $Q_{j}^{\prime \prime}$, calculated as following:

$$
\begin{gathered}
I_{j}=C_{j}+\left(1+M_{j}\right) / 2 \\
C_{j}=\sum_{r=1}^{j-1} M_{r}\left(j>1, j=1, C_{j}=0\right)
\end{gathered}
$$

According to results of risk severity (as shown in Figure 6), we can obtain the number of each severity level: $M_{1}=0, M_{2}=1, M_{3}=4, M_{4}=8, M_{5}=6$. According to Formulas (3) and (4), the ordinal value of risk severity " $I_{j}$ " of each severity level is calculated as following (as shown in Figure 7):

$$
\begin{gathered}
I_{1}=C_{1}+\frac{\left(1+M_{1}\right)}{2}=\frac{1}{2} ; I_{2}=C_{2}+\frac{\left(1+M_{2}\right)}{2}=1 ; I_{3}=C_{3}+\frac{\left(1+M_{3}\right)}{2}=\frac{7}{2} c \\
I_{4}=C_{4}+\frac{\left(1+M_{4}\right)}{2}=\frac{19}{2} ; I_{5}=C_{5}+\frac{\left(1+M_{5}\right)}{2}=\frac{33}{2}
\end{gathered}
$$

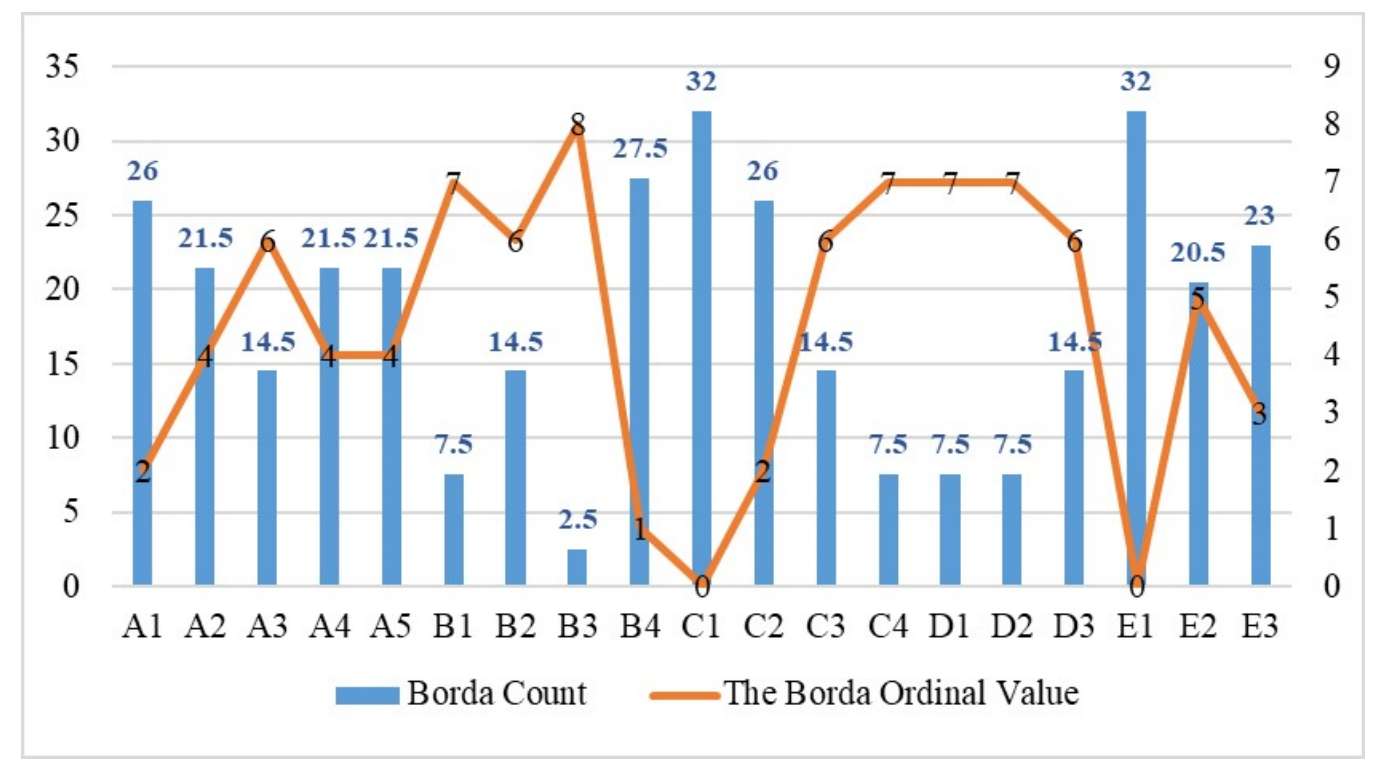

Figure 7. Ranking results of risk perception for Multi-Subject Land Supply Policy. The bar graph represents Borda Count, and the line chart represents Borda ordinal value.

\subsubsection{Determination of Borda Count and Borda Ordinal Value}

Borda count is to measure significance of risks in multi-subject land supply reform. If a risk has the largest Borda Count "Bi" among all risk types, it is the most critical risk [49]. The specific calculation is as following:

$$
B_{i}=\left(N-R_{i 1}\right)+\left(N-R_{i 2}\right)
$$

In Equation (5), " $N$ " represents total number of risks, and total number of risk types herein is 19 . " $i$ " represents a certain type of risk. " $R_{i 1}$ " represents ordinal value of risk severity corresponding to risk " $i^{\prime \prime}$. " $R_{i 2}$ " represents the ordinal value of risk probability corresponding to risk " $i$ ".

The calculation of Borda count is the basis and precondition to determine Borda ordinal value [49]. We sort the result of Borda Count in decending order and assign the values from 0 to 1 in ascending order. Then we get Borda ordinal value (as shown in Figure 7), which is used to represent significance of risk. Borda ordinal value is represented in ascending order from 0 to 1 . It can be seen that the larger the Borda Count, the smaller Borda ordinal value and the higher ranking of risk level. It means that the risk with 
smaller Borda ordinal value is relatively more significant among all risks and deserves more attention. For example, if Borda ordinal value is 0 , it indicates that this risk is the most critical risk.

The ordinal values of various risks are shown in Figure 7 . The ranking results show that the risks with Borda ordinal value of 0 are information asymmetry risk (C1) perceived by farmers and market risk (E1) perceived by banks. It can be derived from the above analysis of Borda ordinal value that, these two risks are the most critical among these potential risks of multi-subject land supply reform. In addition, it can be seen that Borda ordinal value of inadequate fund risk from lease housing construction (B4) perceived by collective economic organizations is 1 . This risk ranks second place in significance of its effect on the reform. Some scholars have noticed the risks of developing collective commercial construction land for rental housing construction $[8,95,96]$. Their research suggests the construction of rental housing requires huge capital investment, while the financial resources of rural collectives are limited. If there is no capital investment or financial support, it is impossible to support the construction and operation of rural collective rental housing only by relying on rental income. Our result also indicates this kind of risk exists. Borda ordinal value of the risk of deteriorating debt crisis (A1) perceived by governments and the agent malpractice risk (C2) perceived by farmers is 2, namely, these two risks rank the third. Moreover, it can be seen from Figure 7 that the risks ranked first focus on two major stakeholders, that is, farmers and banks, followed by the governments. Therefore, in the reform of multi-subject land supply, relevant management departments should prevent the risks perceived by farmers, banks, and local governments, and pay attention to the changes in the land market actively.

\section{Conclusions and Discussion}

In this paper, we analyzed the probability and severity of various types of risks perceived by stakeholders in China's multi-subject land supply reform, as well as the level and ranking of these risks. We selected five types of stakeholders, namely collective economic organizations, farmers, local government, banks and land users, as the respondents of our questionnaire survey. Data were obtained through questionnaires to investigate the probability of risk occurrence and the severity of the consequences. The risk matrix method, frequency analysis and Borda count method were used to analyze the survey results. The following conclusion can be obtained.

- The results show that these stakeholders perceived significant risk, often only one or two, on the premise of the coexistence of multiple risks. The result of risk perception has individual perception difference, which also indicates that these risks do exhibit uncertainty.

- The result of risk grading is a comprehensive effect of risk probability and risk severity. Among all kinds of risks, information asymmetry risk and market risk belong to the high risk level, while other risks belong to the medium level, with the lowest level of accountability risk. Trust is the key factor that affects farmers' participation in the collective. The impact of information asymmetry on farmers is notorious [35].

- Borda count method is a measure of the risk importance of all risk events. From the perspective of stakeholders, farmers and banks have the strongest risk perception, followed by the government. This indicates that, the less available information, the stronger the risk perception.

In the evolution of risk perception theory, some scholars have proposed that factors, such as the amount and type of information, can affect the results of risk perception [97,98]. Scholars represented by Lane and Rollman hold that lack of information is the main cause why the public perceives high risk [99]. "Intermediary projection theory" holds that exogenous factors, such as the amount, transparency and access of information, knowledge structure, communication technology, and media communication, will have somewhat of an effect on the public's risk perception to a certain extent. Moreover, the information reflecting the severity and prevention of risks has different effects on attitude of the pub- 
lic $[100,101]$. The survey finds that farmers were generally less ill-educated and paid little attention to policy information. In the transaction of land, collective economic organizations and local governments have not done well enough in policy publicity and information disclosure, which always keep farmers in a disadvantaged position and perceive information asymmetry risk. Furthermore, collective economic organizations play a leading role in transaction of collective land, and their economic and political powers are too concentrated, which increases the risk of malpractice. Land proceeds are often embezzled by a few of cadres in township and villages, and agent malpractice risk perceived by farmers is also prominent.

Risk assessment and risk control are evaluation and management activities based on people's existing level of risk awareness, so risk perception is an important part of risk awareness [102]. Individual farmers in different countries have different attitudes towards risk [103], some studies have shown that farmers prefer risk averse [104]. Our results also provide further evidence that farmers are risk averse. Risk management strategy is related to farmers' perception and aversion to risk [105]. Studies have shown that risk perception is affected by age, years of education, non-agricultural income, risk experience and other factors $[106,107]$. Compared with actual occurrence of risk, the public's decision-making for risk control is more likely to be influenced by risk perception [23], which results in differences in risk control willingness of public due to different risk perception [108]. In the context of increasing politicization and democratization in risk control, the importance of public risk perception is also increasing. In other words, it is impossible for modern government to bypass the public and act alone in the process of risk control. To formulate rational risk control policy, the government should seek opinion of the public and consider their responses. Therefore, the research of public risk perception should be the premise and foundation for governments to formulate risk control policy. The possible contribution of this article lies in the application of risk matrix and Borda count method to measure risk perception of stakeholders more scientifically, and to explore attitude of the public towards the policy of multi-subject land supply by the survey data, so as to provide a practical basis for effective risk control system and further research of risk control.

From our in-depth interviews and pilot area surveys, we also found that before the reform, more collectively owned land in the pilot area was used for industrial production. These land users in the use of collective land and state-owned land users are different, collective land users do not get the certificate of land use right [57]. The certificate is an important proof for land users to obtain financing support from banks as a mortgage loan, which is also one of the different rights between the use of collective construction land and state-owned construction land [109]. That is to say, before the reform, users of collective land could not obtain funds to develop enterprises through mortgage of land use right, which hindered the growth of enterprises. On the other hand, it also shows that before the reform, the collective profit-oriented construction land and state-owned land differ greatly in terms of rights and interests. Therefore, in this context, the marketization of collective construction land in the pilot areas mainly solves the above historical problems. The aim is to help land companies without collective land use right certificate to obtain collective land use right, so that they can have the same rights to land as state-owned land users and can get fund from banks with land-use rights mortgages. They are active promoters of this policy, but after their problems have been solved, whether the real market demand will still be strong, this is a question to be considered in the future.

At the present stage, although the potential risk level of multi-subject land supply reform is not high, there are still some problems in the reform process that need to be further considered. How to increase the proportion of land value-added revenue of farmers? How to guard against market risks that banks may face? How to realize the collective-owned construction land and the state-owned land with the same right, the same price, the same responsibility? These are the key issues that need to be addressed in future pilot areas [110]. Considering the above, the government departments should probably take targeted risk prevention measures to deal with the change situation of reform and development. For 
instance, further improvement of the benefit distribution rules and publicity, as well as to track and release timely information on land transactions. It may be necessary to raise the disclosure rate of land transaction information and enrich information transmission channels. Moreover, more laws, policies and regulation are need to inform farmers so as to make up for the disadvantages of farmers' access to information and reduce the risk of information asymmetry [76]. For example, relevant supporting policies should be issued as soon as possible to clarify the construction, fire control, environmental protection and other related licensing issues that will be involved in the subsequent development of the collective profit-oriented construction land.

Author Contributions: Conceptualization, Z.Q. and Y.W.; methodology, Z.Q. and Y.W.; software, Y.W.; investigation, Y.W. and X.L.; data curation, Y.W. and X.L.; resource, Y.W. and X.L.; visualization, Y.W.; formal analysis, Z.Q. and Y.W.; writing-original draft, Z.Q. and Y.W.; writing-review and editing, Z.Q.; supervision, Z.Q.; project administration, Z.Q.; funding acquisition, Z.Q. All authors have read and agreed to the published version of the manuscript.

Funding: This article was financially supported by the Humanities and Social Sciences Planning Fund Projects of the Ministry of Education of China (Project No. 18YJAZH071), the Key Project of Jiangsu Provincial Philosophy and Social Science (Project No. 2017ZDIXM099), Nanjing Agricultural University Humanities and Social Sciences Priority Projects (Project No. SKYZ2018037), and the Demonstration Course Project of Ideological and Political of Nanjing Agricultural University (Project No. KCSZ2020066).

Institutional Review Board Statement: Not applicable.

Informed Consent Statement: Informed consent was obtained from all subjects involved in the study. Data Availability Statement: Not applicable.

Acknowledgments: The authors acknowledge Duo Wan, Xiaole Wang and Yanhuan Li for assisting the field investigation.

Conflicts of Interest: The authors declare no conflict of interest. 


\section{Appendix A}

Table A1. Questionnaire of multi-subject land supply risk perception.

\begin{tabular}{|c|c|c|c|c|}
\hline Respondent & Variable Code & & Question & Assessment \\
\hline \multirow{9}{*}{ Government workers and experts } & \multirow[t]{2}{*}{ A1 } & $1-\mathrm{a}$ & $\begin{array}{l}\text { Do you think the marketization of collective-owned } \\
\text { construction land has an impact on local government fiscal } \\
\text { revenue and its solvency? }\end{array}$ & $\begin{array}{l}\text { 1-No influence, 2-Little influence, 3-Medium, 4-Big } \\
\text { influence, 5- Great influence }\end{array}$ \\
\hline & & $1-b$ & $\begin{array}{l}\text { Do you think there will be a serious debt crisis for local } \\
\text { governments affected by this? }\end{array}$ & $\begin{array}{c}\text { 1-Negligible degree, } 2 \text { - Less serious, 3-Medium, 4-More } \\
\text { serious, 5-Very serious }\end{array}$ \\
\hline & \multirow[t]{2}{*}{$\mathrm{A} 2$} & $2-\mathrm{a}$ & $\begin{array}{l}\text { Do you think the marketization of collective-owned } \\
\text { construction land will make land expropriation more difficult } \\
\text { for the local government in the future? }\end{array}$ & $\begin{array}{l}\text { 1-No possibility, 2-Less likely, 3-Medium, 4-High } \\
\text { probability, 5-Most likely }\end{array}$ \\
\hline & & $2-b$ & $\begin{array}{l}\text { Do you think the government will raise the standard of land } \\
\text { compensation for farmers? }\end{array}$ & $\begin{array}{c}\text { 1-Unchanged, 2-Little, 3-Medium, 4-Larger, 5-The } \\
\text { largest }\end{array}$ \\
\hline & \multirow[t]{2}{*}{ A3 } & $3-\mathrm{a}$ & $\begin{array}{l}\text { Do you think the collective economic organization, to get } \\
\text { more profits, would trade some agricultural land or some land } \\
\text { with disputes as construction land for market transactions? }\end{array}$ & $\begin{array}{l}\text { 1-No possibility, 2-Less likely, 3-Medium, 4-High } \\
\text { probability, 5-Most likely }\end{array}$ \\
\hline & & $3-b$ & $\begin{array}{l}\text { If the use of collective land is illegally changed, how much do } \\
\text { you think the loss of land is? }\end{array}$ & $\begin{array}{l}\text { 1-Negligible degree, } 2 \text { - Less serious, 3-Medium, 4-More } \\
\text { serious, } 5 \text {-Very serious }\end{array}$ \\
\hline & A4 & $4-b$ & $\begin{array}{l}\text { How much do you think this will affect the balance of supply } \\
\text { and demand in the housing market? }\end{array}$ & $\begin{array}{c}\text { 1-Negligible degree, } 2 \text { - Less serious, 3-Medium, 4-More } \\
\text { serious, 5-Very serious }\end{array}$ \\
\hline & \multirow[t]{2}{*}{ A5 } & $5-\mathrm{a}$ & $\begin{array}{l}\text { Do you think the real estate market will be impacted after the } \\
\text { land market allows multiple subjects to supply land and the } \\
\text { new housing policy is implemented? }\end{array}$ & $\begin{array}{l}\text { 1-No influence, 2-Little influence, 3-Medium, 4-Big } \\
\text { influence, 5-Great influence }\end{array}$ \\
\hline & & $5-b$ & $\begin{array}{l}\text { How much do you think the price of real estate will be } \\
\text { affected by this? }\end{array}$ & $\begin{array}{c}\text { 1-Unchanged, 2-Little, 3-Medium, 4-Larger, 5-The } \\
\text { largest }\end{array}$ \\
\hline
\end{tabular}


Table A1. Cont.

\section{Respondent} Variable Code Question

Question

After collective construction land is transferred or leased, do you think to have the circumstance that land users do not press agreement pay assignment gold or rent?

B1

Collective economic organizations

If this happens, how much do you think it will affect the

1-b village's income?

2-a In the process of land use, is there any dispute between the land user and the villagers or the village committee?

B2

If that happens, do you think these disputes and similar problems will be easy to deal with?

After the collective construction land is transferred or leased,

does the land user not use the land according to the prescribed

purposes?

B3 the village?

Collective economic organizations Does the village

4-a Does the village collective have enough money for the construction of rental houses?

B4

4-b Do you think it will be easy to raise money if there is not enough money?

1-a Do you understand the current reform of collective profit-oriented construction land in the village?

C1 Is there a unified distribution standard about the income of

1-b the marketization of collective-owned construction land?

Will the collective economic organization announce to the

Farmers 2-a farmers the specific situation of the collective construction land transaction?
Assessment

1-Never occurs, 2-Individual cases, 3-Less parts, 4-Occur more, 5- Almost all

1-Negligible degree, 2-Less serious, 3-Medium, 4-More serious, 5-Very serious

1-Never happened, 2-Once or twice, 3-Four or five times, 4-Less than 10 times, 5-More than 10 times

1-Easy to deal with, 2-A little difficult, 3-Medium, 4-Difficult, 5-Very difficult

1-Never happened, 2-Once or twice, 3-Three or four times,

4-Less than six times, 5-More than six times

1-Negligible degree, 2-Less serious, 3-Medium, 4-More serious, 5-Very serious

1-Very abundant, 2-Basically abundant, 3-A little bit inadequate, 4-Big funding gap, 5-Severely underfunded

1-Easy to deal with, 2-A little difficult, 3-Medium, 4 -Difficult, 5-Very difficult

1-Know very well, 2-Understand better, 3-Medium, 4-Know little, 5-Not at all clear

1-Standard clear, 2-Relatively clear, 3-A little vague, 4 -Very vague, 5 - No standard

1-Announce all deals, 2-Announce most of the deals,

3-Announce a minority of deals, 4-Announce very few deals, 5-Never announce a deal

1-No influence, 2-Little influence, 3-Medium, 4-Big According to the income you have received, do you think the your income? 
Table A1. Cont. Respondent Variable Code

C3 Question

\section{Assessment}

According to the distribution of income in your village, do you think the income you have received is reasonable and acceptable?

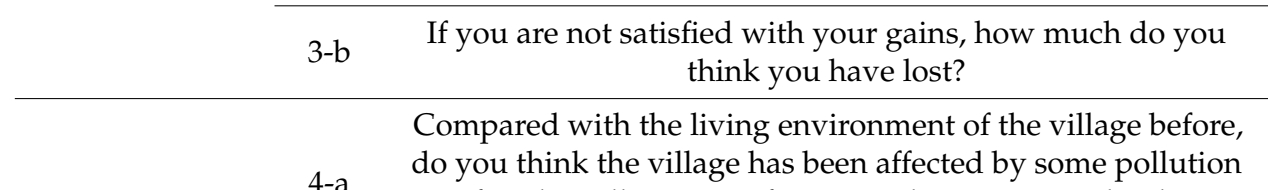

C4

you think the village has been affected by some pollution transferred or leased to enterprises?

4-b If so, to what extent do you think this has affected your life? At present, laws and policies related to land supply system reform have not been improved, and there are constraint

1-a reform have not been improved, and there are constrain
conflicts. Does this affect your land development and

D1

$$
\text { construction? }
$$

1-b If so, how much damage do you think it will do to your own earnings?

1-Minimal loss, 2-Relatively small, 3-Medium, 4-Big loss, 5-Great loss

Land users

Compared with the land acquired from the government

before, do you think the development cost will increase due to

2-a the land reclamation and land consolidation expenses when the land is directly acquired from the peasant collective for

1-Unchanged, 2-Little, 3-Medium, 4-Larger, 5-The the land is directly acquired from the
development?

ases, how much do you think the loss will be to

2-b If the cost increases, how much do you think the
the final investment income?

1-No loss, 2-Very few losses, 3-Relatively small,

3-a How much do you think the clarity of land ownership affects the outcome of collective land financing?

1-No influence, 2-Little influence, 3-Medium, 4-Big influence, 5-Great influence

1-Very reasonable, 2-Relatively reasonable, 3-Medium, 4-Less reasonable, 5-Unreasonable

1-Minimal loss, 2-Relatively small, 3-Medium, 4-Big loss,

1-No influence, 2-Little influence, 3-Medium, 4-Big influence, 5-Great influence

1-Negligible degree, 2-Less serious, 3-Medium, 4-More serious, 5-Very serious

1-No influence, 2-Little influence, 3-Medium, 4-Big influence, 5-Great influence 
Table A1. Cont.

The "multi-subject land supply" reform increased the land supply and affected the land price. According to the bank's previous loan situation, do you think the changes in market conditions will have an impact on the bank's loan income?

1-b If so, to what extent do you think it will affect bank earnings?

Are there any cases in which the bank takes legal risks due to

disputes arising from the unclear definition of collective land

Banks land?
1-No influence, 2-Little influence, 3-Medium, 4-Big influence, 5-Great influence

1-Minimal loss, 2-Relatively small, 3-Medium, 4-Big loss, 5-Great loss

1-Never happened, 2-Once or twice, 3-Three or four times,

2-b If so, how much impact do you think it will have on the work

$$
\text { of banks? }
$$

1-Negligible degree, 2-Less serious, 3-Medium, 4-More

In the process of the bank's financial support to the

3-a marketization of collective profit-oriented construction land, is

1-Never happened, 2-Once or twice, 3-Three or four times, repay the bank loan on time?

3-b If there is a similar situation, what do you think is the loss of 1-Minimal loss, 2—Relatively small, 3-Medium, 4-Big loss, earnings for the bank? 5 -Great loss 


\section{References}

1. United States Department of Agriculture. Report Name: China's 2020 Agricultural Policy Document Stays the Course; United States Department of Agriculture: Washington, DC, USA, 2020.

2. Tan, R.; Wang, R.; Heerink, N. Liberalizing rural-to-urban construction land transfers in China: Distribution effects. China Econ. Rev. 2020, 60, 101147. [CrossRef]

3. Lai, Y.; Peng, Y.; Li, B.; Lin, Y. Industrial land development in urban villages in China: A property rights perspective. Habitat Int. 2014, 41, 185-194. [CrossRef]

4. Liu, Y.; Fang, F.; Li, Y. Key issues of land use in China and implications for policy making. Land Use Policy 2014, 40, 6-12. [CrossRef]

5. Lin, Y. Analysis of land supply policy under the housing system of "simultaneous Purchase and Rent". China Land 2019, 5, 8-11.

6. Chen, S.; Ye, J.; Wang, F. Innovation of multi-subject land supply channel and property right disposal mode. China Land 2018, 5, 49-51.

7. Dong, Z. What does multi-subject land supply mean? China Land Resources Newspaper, 23 January 2018.

8. Huang, Y.; Zhang, C. Speeding up the Establishment of a Housing System That Ensures Supply through Multiple Sources, Provides Housing Support Through Multiple Channels, and Encourages Both Housing Purchase and Renting. Price Theory Pract. 2017, 11, 15-20.

9. Nguyen, H.; Duan, J.; Zhang, G. Land Politics under Market Socialism: The State, Land Policies, and Rural-Urban Land Conversion in China and Vietnam. Land 2018, 7, 51. [CrossRef]

10. Mao, B.; Ao, C.; Cheng, Y.; Jiang, N.; Xu, L. Exploring the role of public risk perceptions on preferences for air quality improvement policies: An integrated choice and latent variable approach. J. Clean. Prod. 2020, 269, 122379. [CrossRef]

11. Slovic, P. The feeling of risk: New perspectives on risk perception. Energy Environ. 2010, 22, 835-836. [CrossRef]

12. Slovic, P. Perception of risk. Science 1987, 236, 280-285. [CrossRef]

13. Wildavsky, A.; Dake, K. Theories of Risk Perception: Who Fears What and Why? Daedalus 1990, 119, 41-60.

14. Li, X.; Liu, T. Community participation effects on preparedness behaviour through risk perception: Empirical data of hazardous chemicals from China. Int. J. Disaster Risk Reduct. 2020, 44, 101421. [CrossRef]

15. Maestas, C.; Chattopadhyay, J.; Leland, S.; Piatak, J. Fearing Food: The Influence of Risk Perceptions on Public Preferences for Uniform and Centralized Risk Regulation. Policy Stud. J. 2020, 48, 447-468. [CrossRef]

16. Lindell, M.K.; Barnes, V.E. Protective response to technological emergency: Risk perception and behavioral intention. J. Saf. Res. 1989, 20, 45. [CrossRef]

17. Vaughan, E. Chronic exposure to an environmental hazard: Risk perceptions and self-protective behavior. Health Psychol. 1993, 12, 74-85. [CrossRef]

18. Shapira, S.; Aharonson-Daniel, L.; Bar-Dayan, Y. Anticipated behavioral response patterns to an earthquake: The role of personal and household characteristics, risk perception, previous experience and preparedness. Int. J. Disaster Risk Reduct. 2018, 31, 1-8. [CrossRef]

19. Slovic, P.; Finucane, M.L.; Peters, E.; MacGregor, D.G. Risk as Analysis and Risk as Feelings: Some Thoughts about Affect, Reason, Risk, and Rationality. Risk Anal. 2004, 24, 311-322. [CrossRef]

20. Slovic, P.; Peters, E. Risk Perception and Affect. Curr. Dir. Psychol. Sci. 2006, 15, 322-325. [CrossRef]

21. Johnston, D.M.; Lai, M.S.; Houghton, B.F.; Paton, D. Volcanic hazard perceptions: Comparative shifts in knowledge and risk. Disaster Prev. Manag. Int. J. 1999, 8, 118-126. [CrossRef]

22. Pu, S.; Shao, Z.; Yang, L.; Liu, R.; Bi, J.; Ma, Z. How much will the Chinese public pay for air pollution mitigation? A nationwide empirical study based on a willingness-to-pay scenario and air purifier costs. J. Clean Prod. 2019, 218, 51-60. [CrossRef]

23. Wauters, E.; van Winsen, F.; de Mey, Y.; Lauwers, L. Risk perception, attitudes towards risk and risk management: Evidence and implications. Agric. Econ. 2014, 60, 389-405. [CrossRef]

24. Bekiros, S.; Jlassi, M.; Naoui, K.; Uddin, G.S. Risk perception in financial markets: On the flip side. Int. Rev. Financ. Anal. 2018, 57, 184-206. [CrossRef]

25. Wu, W.; Zheng, J.; Fang, Q. How a typhoon event transforms public risk perception of climate change: A study in China. J. Clean. Prod. 2020, 261, 121163. [CrossRef]

26. Khwaja, A.; Sloan, F.; Salm, M. Evidence on preferences and subjective beliefs of risk takers: The case of smokers. Int. J. Ind. Organ. 2006, 24, 667-682. [CrossRef]

27. Sutter, M.; Kocher, M.G.; Glätzle-Rützler, D.; Trautmann, S.T. Impatience and Uncertainty: Experimental Decisions Predict Adolescents' Field Behavior. Am. Econ. Rev. 2013, 103, 510-531. [CrossRef]

28. Soler, L.; Verburg, P.; Alves, D. Evolution of Land Use in the Brazilian Amazon: From Frontier Expansion to Market Chain Dynamics. Land 2014, 3, 981-1014. [CrossRef]

29. Iyer, P.; Bozzola, M.; Hirsch, S.; Meraner, M.; Finger, R. Measuring Farmer Risk Preferences in Europe: A Systematic Review. J. Agric. Econ. 2020, 71, 3-26. [CrossRef]

30. Ahmed, Z.; Guha, G.S.; Shew, A.M.; Alam, G.M.M. Climate change risk perceptions and agricultural adaptation strategies in vulnerable riverine char islands of Bangladesh. Land Use Policy 2021, 103, 105295. [CrossRef] 
31. Riwthong, S.; Schreinemachers, P.; Grovermann, C.; Berger, T. Agricultural commercialization: Risk perceptions, risk management and the role of pesticides in Thailand. Kasetsart J. Soc. Sci. 2017, 38, 264-272. [CrossRef]

32. Pinillos, D.; Poccard-Chapuis, R.; Bianchi, F.J.; Corbeels, M.; Timler, C.J.; Tittonell, P.; Ballester, M.V.; Schulte, R.P. Landholders' perceptions on legal reserves and agricultural intensification: Diversity and implications for forest conservation in the eastern Brazilian Amazon. For. Policy Econ. 2021, 129, 102504. [CrossRef]

33. El Benni, N.; Finger, R.; Meuwissen, M.P.M. Potential effects of the income stabilisation tool (IST) in Swiss agriculture. Eur. Rev. Agric. Econ. 2016, 43, 475-502. [CrossRef]

34. Meuwissen, M.P.M.; de Mey, Y.; van Asseldonk, M. Prospects for agricultural insurance in Europe. Agric. Financ. Rev. 2018, 78, 174-182. [CrossRef]

35. Giampietri, E.; Yu, X.; Trestini, S. The role of trust and perceived barriers on farmer's intention to adopt risk management tools. Bio-Based Appl. Econ. 2020, 9, 1-24. [CrossRef]

36. Qu, C.; Ren, D. Impact of Rural Construction Land Marketization on Rural Development. China Land Sci. 2018, $32,36-41$.

37. Shen, D. Study on the Influence Mechanism of Collective Commercial Construction Land on Rural Transformation and Development. Master's Thesis, Qufu Normal University, Jining, China, 2020.

38. Sroka, W.; Żmija, D. Farming Systems Changes in the Urban Shadow: A Mixed Approach Based on Statistical Analysis and Expert Surveys. Agriculture 2021, 11, 455. [CrossRef]

39. Zhu, W.; Yao, N.; Guo, Q.; Wang, F. Public risk perception and willingness to mitigate climate change: City smog as an example. Environ. Geochem. Health 2020, 42, 881-893. [CrossRef] [PubMed]

40. Ridolfi, E.; Albrecht, F.; Di Baldassarre, G. Exploring the role of risk perception in influencing flood losses over time. Hydrol. Sci. J. 2020, 65, 12-20. [CrossRef]

41. Khan, N.A.; Gao, Q.; Iqbal, M.A.; Abid, M. Modeling food growers' perceptions and behavior towards environmental changes and its induced risks: Evidence from Pakistan. Environ. Sci. Pollut. Res. 2020, 27, 20292-20308. [CrossRef] [PubMed]

42. McEvoy, J.; Gilbertz, S.J.; Anderson, M.B.; Ormerod, K.J.; Bergmann, N.T. Cultural theory of risk as a heuristic for understanding perceptions of oil and gas development in Eastern Montana, USA. Extr. Ind. Soc. 2017, 4, 852-859. [CrossRef] [PubMed]

43. Lacasse, K. Going with your gut: How William James' theory of emotions brings insights to risk perception and decision making research. New Ideas Psychol. 2017, 46, 1-7. [CrossRef]

44. Flaten, O.; Lien, G.; Koesling, M.; Valle, P.S.; Ebbesvik, M. Comparing risk perceptions and risk management in organic and conventional dairy farming: Empirical results from Norway. Livest. Prod. Sci. 2005, 95, 11-25. [CrossRef]

45. Vollmer, E.; Hermann, D.; Mußhoff, O. Is the risk attitude measured with the Holt and Laury task reflected in farmers' production risk? Eur. Rev. Agric. Econ. 2017, 44, 399-424. [CrossRef]

46. Xia, N.; Xie, Q.; Hu, X.; Wang, X.; Meng, H. A dual perspective on risk perception and its effect on safety behavior: A moderated mediation model of safety motivation, and supervisor's and coworkers' safety climate. Accid. Anal. Prev. 2020, 134, 105350. [CrossRef]

47. Van der Linden, S. The social-psychological determinants of climate change risk perceptions: Towards a comprehensive model. J. Environ. Psychol. 2015, 41, 112-124. [CrossRef]

48. Hu, X.; Wang, F.; Wei, J. Optimal decision model for emergency resource reserves in chemical industrial parks in China: A risk perception perspective. Process Saf. Prog. 2019, 38, 21-28. [CrossRef]

49. Li, S. The Application of Risk Matrix in Enterprise Risk Management; People Post Press: Beijing, China, 2013.

50. Akano, D.I.; Ijomah, W.; Windmill, J. Stakeholder considerations in remanufacturability decision-making: Findings from a systematic literature review. J. Clean. Prod. 2021, 298, 126709. [CrossRef]

51. Du, L.; Feng, Y.; Lu, W.; Kong, L.; Yang, Z. Evolutionary game analysis of stakeholders' decision-making behaviours in construction and demolition waste management. Environ. Impact Assess. Rev. 2020, 84, 106408. [CrossRef]

52. Schueller, L.; Booth, L.; Fleming, K.; Abad, J. Using serious gaming to explore how uncertainty affects stakeholder decision-making across the science-policy divide during disasters. Int. J. Disaster Risk Reduct. 2020, 51, 101802. [CrossRef]

53. Wang, X. The Influence Path of Public Environmental Risk Perception on Behavior Choice. J. Jishou Univ. Soc. Sci. 2019, 40, 114-123.

54. Moon, W.-K.; Kahlor, L.A.; Olson, H.C. Understanding public support for carbon capture and storage policy: The roles of social capital, stakeholder perceptions, and perceived risk/benefit of technology. Energy Policy 2020, 139, 111312. [CrossRef]

55. Santoro, S.; Pluchinotta, I.; Pagano, A.; Pengal, P.; Cokan, B.; Giordano, R. Assessing stakeholders' risk perception to promote Nature Based Solutions as flood protection strategies: The case of the Glinščica river (Slovenia). Sci. Total Environ. 2019, 655, 188-201. [CrossRef]

56. Harclerode, M.A.; Lal, P.; Vedwan, N.; Wolde, B.; Miller, M.E. Evaluation of the role of risk perception in stakeholder engagement to prevent lead exposure in an urban setting. J. Environ. Manag. 2016, 184, 132-142. [CrossRef] [PubMed]

57. Qu, F. Land Economics; China Agricultural Press: Beijing, China, 2011.

58. Yuan, F.; Yan, X. Trilateral Game Analysis on Collective Construction Land Transfer: In View of Local Governments, Rural Collectivesand Land Using Enterprises. China Land Sci. 2009, 23, 58-63.

59. Xu, J.; Li, G. How is Rural Land Marketization Possible?-Cases Study Based on the Approach of Double Influences. J. Public Manag. 2019, 16, 108-117+173.

60. Bian, Y.; Li, Y. Land Administration Law of the People's Republic of China; China Legal Publishing House: Beijing, China, 1998. 
61. Wang, Y. Research on Rural Land Management Mode under Four Modernizations Synchronization-Based on the Practice of Zhanjiang, Guangdong. Econ. Geogr. 2015, 35, 157-164.

62. Tong, W.; Lo, K.; Zhang, P. Land Consolidation in Rural China: Life Satisfaction among Resettlers and Its Determinants. Land 2020, 9, 118. [CrossRef]

63. Long, K. Rural Collective Construction Land Transfer: Evolution, Mechanism Regulation and Control. Ph.D. Thesis, Nanjing Agricultural University, Nanjing, China, 2009.

64. Wang, J.; Li, Y.; Wang, Q.; Cheong, K.C. Urban-Rural Construction Land Replacement for More Sustainable Land Use and Regional Development in China: Policies and Practices. Land 2019, 8, 171. [CrossRef]

65. Freeman, R.E. Strategic Management: A Stakeholder Approach; Cambridge University Press: Cambridge, UK, 2010. [CrossRef]

66. Poku-Boansi, M. Multi-stakeholder involvement in urban land use planning in the Ejisu Municipality, Ghana: An application of the social complexities' theory. Land Use Policy 2021, 103, 105315. [CrossRef]

67. Rose, J.; Flak, L.S.; Sæbø, Ø. Stakeholder theory for the E-government context: Framing a value-oriented normative core. Gov. Inf. Q. 2018, 35, 362-374. [CrossRef]

68. Burt, G.; Mackay, D.; Mendibil, K. Overcoming multi-stakeholder fragmented narratives in land use, woodland and forestry policy: The role scenario planning and 'dissociative jolts'. Technol. Forecast. Soc. Chang. 2021, 166, 120663. [CrossRef]

69. Qu, Z.; Lu, Y.; Jiang, Z.; Bassett, E.; Tan, T. A Psychological Approach to 'Public Perception' of Land-Use Planning: A Case Study of Jiangsu Province, China. Sustainability 2018, 10, 3056. [CrossRef]

70. Hannachi, M.; Fares, M.; Coleno, F.; Assens, C. The "new agricultural collectivism": How cooperatives horizontal coordination drive multi-stakeholders self-organization. J. Co-Oper. Organ. Manag. 2020, 8, 100111. [CrossRef]

71. Wu, Y.; Wu, Y.; Shang, Y.; Guo, H.; Wang, J. Social network efficiency of multiple stakeholders on agricultural drought risk governance-A southern China case study. Int. J. Disaster Risk Reduct. 2020, 51, 101772. [CrossRef]

72. Ingram, J.; Gaskell, P.; Mills, J.; Dwyer, J. How do we enact co-innovation with stakeholders in agricultural research projects? Managing the complex interplay between contextual and facilitation processes. J. Rural Stud. 2020, 78, 65-77. [CrossRef]

73. Xia, F.; Yan, J. Direct transfer of rural collective construction land into the market: Role, risks and suggestions. Econ. Restruct. 2014, 3, 70-74.

74. Wang, H.; Tao, R. On the "Zhejiang Mode" of land Development Right Transfer and Trade-The origin of system, operation mode and its important meaning. Manag. World 2009, 8, 39-52.

75. Zheng, J. Local government financial pressure, land transfer revenue and real estate prices—Evidence from China's 35 cities panel data. Macroecon. Res. 2020, 2, 63-74+175.

76. Lu, J.; Chen, Z. Pilot Reform of Collective Operation Land for Construction: Difficulties and Solutions. J. Nanjing Agric. Univ. Soc. Sci. Ed. 2019, 19, 112-122+159.

77. Yang, J.; Jiang, J.; He, J.; Zhang, Y. Land finance problems under the perspective of central-local relationship. Times Financ. 2019, $28,80-84$.

78. Shi, J.; Wei, M. A Study on compensated Adjustment of Land Consolidation Index under plan Management—A case study of Zhejiang Province. Rural Econ. 2011, 4, 40-43.

79. Liu, J.; Yin, Q.; Tang, H.; Zhang, Z. A supervisory game model for village committees' behavior in the marketilization of rural commercial collective-Owned construction land. J. Univ. Chin. Acad. Sci. 2018, 35, 805-813.

80. Chen, Y.; Li, M.; Xiao, J.; Tang, P. Game analysis of value-added income distribution of collective operational construction land in the market-Taking Chengdu's Pidu District as an example. South Land Resour. 2019, 11, 39-43+47.

81. Han, S. The ownership of collective profit-oriented construction land and its coordination with the land expropriation system in the process of urbanization. Contemp. Law 2016, 30, 69-80.

82. Guo, X.; Feng, S.; Lv, P.; Liu, Z. The Economical and Intensive Use of Construction Land: A Case Study on Old Town, Old Village and Old FactoryTransformation in Foshan. Resour. Sci. 2014, 36, 1554-1562.

83. He, H.; Ye, L. Practice and Consideration on the Reform of Collective Commercial Construction Land Market-Taking Wujin District, Changzhou City, Jiangsu Province as an Example. China Land 2018, 1, 43-45.

84. Frank, K. Risk, Uncertainty, and Profit; Huaxia Press: Beijing, China, 2013.

85. Ni, H.; Chen, A.; Chen, N. Some extensions on risk matrix approach. Saf. Sci. 2010, 48, 1269-1278. [CrossRef]

86. Khan, F.I.; Amyotte, P.R.; Amin, M.d.T. Advanced methods of risk assessment and management: An overview. Methods Chem. Process Saf. 2020, 4, 1-34. [CrossRef]

87. Khan, F.; Rathnayaka, S.; Ahmed, S. Methods and models in process safety and risk management: Past, present and future. Process Saf. Environ. Prot. 2015, 98, 116-147. [CrossRef]

88. Zahid, M.A.; de Swart, H. The Borda Majority Count. Inf. Sci. 2015, 295, 429-440. [CrossRef]

89. Neveling, M.; Rothe, J. Control complexity in Borda elections: Solving all open cases of offline control and some cases of online control. Artif. Intell. 2021, 298, 103508. [CrossRef]

90. Liao, H.; Wu, X.; Mi, X.; Herrera, F. An integrated method for cognitive complex multiple experts multiple criteria decision making based on ELECTRE III with weighted Borda rule. Omega 2020, 93, 102052. [CrossRef]

91. Lu, X. Social Survey Research Practice Course; People Post Press: Beijing, China, 2016.

92. Potchana, K.; Saengsuwan, J.; Kittipanya-ngam, P. Validity and Test-Retest Reliability of a Thai Stroke Physical Activity Questionnaire. J. Stroke Cerebrovasc. Dis. 2021, 30, 105907. [CrossRef] 
93. Lucas, C.; Muraleedharan, G.; Guedes Soares, C. Assessment of the uncertainty of estimated extreme quantiles by regional frequency analysis. Ocean Eng. 2019, 190, 106347. [CrossRef]

94. Hu, L.; Nikolopoulos, E.I.; Marra, F.; Morin, E.; Marani, M.; Anagnostou, E.N. Evaluation of MEVD-based precipitation frequency analyses from quasi-global precipitation datasets against dense rain gauge networks. J. Hydrol. 2020, 590, 125564. [CrossRef]

95. Lin, Y. Commodity residential land for the New Deal analysis. China Land 2018, 7, 16-18.

96. Long, Z.; Mo, F. Challenges and solutions of rural collective construction land entering rental housing market. Reform 2019, 3, 30-37.

97. Popovic, N.F.; Bentele, U.U.; Pruessner, J.C.; Moussaïd, M.; Gaissmaier, W. Acute Stress Reduces the Social Amplification of Risk Perception. Sci. Rep. 2020, 10, 7845. [CrossRef]

98. Holzmeister, F.; Huber, J.; Kirchler, M.; Lindner, F.; Weitzel, U.; Zeisberger, S. What Drives Risk Perception? A Global Survey with Financial Professionals and Laypeople. Manag. Sci. 2020, 66, 3977-4002. [CrossRef]

99. Renn, O.; Rohrmann, B. (Eds.) Cross-Cultural Risk Perception: A Survey of Empirical Studies; Springer: New York, NY, USA, 2000. [CrossRef]

100. Wang, G.; Xu, Y. The Influence Factor of Public Perceived Risk: A Two-Dimensional Examination from Interestand InformationBased on the Empirical Analysis of L City. J. Northeast Univ. Soc. Sci. 2020, 22, 73-80.

101. Mustafiz, S.; Nakayasu, A.; Itabashi, M. Marketing of Vegetable Seeds: Practice and Behavioral Inclinations of Vegetable Seed Sellers and Farmers in Selected Areas of Bangladesh. Agriculture 2021, 11, 364. [CrossRef]

102. Tam, J.; McDaniels, T.L. Understanding individual risk perceptions and preferences for climate change adaptations in biological conservation. Environ. Sci. Policy 2013, 27, 114-123. [CrossRef]

103. Altobelli, F.; Marta, A.D.; Heinen, M.; Jacobs, C.; Giampietri, E.; Mancini, M.; Cimino, O.; Trestini, S.; Kranendonk, R.; Chanzy, A.; et al. Irrigation Advisory Services: Farmers preferences and willingness to pay for innovation. Outlook Agric. 2021. [CrossRef]

104. Binici, T.; Koç, A.A.; Zulauf, C.R.; Bayaner, A. Risk attitudes of farmers in terms of risk aversion: A case study of Lower Seyhan Plain farmers in Adana Province. Turkey. Turk. J. Agric. For. 2003, 27, 305-312.

105. Sulewski, P.; Kłoczko-Gajewska, A. Farmers' risk perception, risk aversion and strategies to cope with production risk: An empirical study from Poland. Stud. Agric. Econ. 2014, 116, 140-147. [CrossRef]

106. Ullah, R.; Shivakoti, G.P.; Ali, G. Factors effecting farmers' risk attitude and risk perceptions: The case of Khyber Pakhtunkhwa, Pakistan. Int. J. Disaster Risk Reduct. 2015, 13, 151-157. [CrossRef]

107. Bampasidou, M.; Kaller, M.D.; Tanger, S.M. Stakeholder's Risk Perceptions of Wild Pigs: Is There a Gender Difference? Agriculture 2021, 11, 329. [CrossRef]

108. Alam, M.d.A.; Guttormsen, A.G. Risk in aquaculture: Farmers' perceptions and management strategies in Bangladesh. Aquac. Econ. Manag. 2019, 23, 359-381. [CrossRef]

109. Jin, X. Scientific Connotation and Realization of "Same Right and Same Price" of Collective and State-owned Land. J. Agric. Econ. 2017, 9, 14-20.

110. Huang, X. Establishment of the Integrated Urban-Rural Construction Land Market System. China Land Sci. 2019, 33, 1-7. 